\title{
Olümpiavõitja kui rahvuskangelane: folkloristlik vaade ühele dopingujuhtumile ${ }^{1}$
}

\begin{abstract}
Piret Voolaid
Teesid: Artikli keskmes on usu, uskumise ja usaldamise kategooriad ja neid väljendavad diskursused kahekordse olümpiavõitja, Eesti murdmaasuusataja Andrus Veerpaluga seotud dopinguskandaalis, mis puhkes 2011. aasta aprillis Eesti meediaväljaannetes ja pälvis avalikkuses erakordset tähelepanu kuni õigeksmõistva kohtuotsuse langetamiseni märtsis 2013.

Pärast šokeerivat uudist muutus rahva poolehoiu retooriliseks ekvivalentsiks dopingusüüdistuse saanud sportlase uskumine ja usaldamine. Usk ja usaldus tõusis esiplaanile nt sündmust kajastavate artiklite veebikommentaarides, solidaarsuse väljendusena loodud Facebooki kogukondade, nt "Usume Andrus Veerpalu" postitustes, mitme linna keskväljakul korraldatud inimkettides, osutades konkreetse sportlase staatusele kogukonnas ja moodustades uurimuses tõsimeelse toetajate diskursuse. Kogu tegevuse foonil on irooniline diskursus, mis seab kahtluse alla sportlase aususe ja esiplaanile teemast ükskõikse üleoleku, väljendub sagedamini sportlase suhtes negatiivse hinnanguga kommentaarides, sündmuse järel tekkinud paroodiates. Kirjutises analüüsitakse olümpiakangelase kui rahvusliku sümboli ja müüdi ning temasse uskumise ilminguid folklooris, mida võib žanriliselt nimetada nt tänapäeva linnamuistenditeks, vandenõulugudeks, naljandeiks ja anekdootideks.
\end{abstract}

Märksõnad: dopingulood, fännikultuur, kangelane, rahvuslik identiteet, spordifolkloor, stereotüübid, usk, vandenõuteooriad

\section{Sissejuhatuseks}

Käesolev kirjutis on 2011. aasta aprillis eesti meedias ühe olümpiavõitja ümber puhkenud dopinguskandaali folkloristlik analüüs. 23. veebruaril 2011 teatas Eesti endine murdmaasuusataja, kahekordne maailmameister ja kahekordne olümpiavõitja Andrus Veerpalu, et ei osale tervislikel põhjustel eesseisvatel Holmenkolleni maailmameistrivõistlustel ja lõpetab oma sportlasekarjääri. Poolteist kuud hiljem, 2. aprillil 2011 ilmus Postimehes Tuuli Kochi ja Peep Pahvi sensatsiooniline artikkel (Koch \& Pahv 2011), milles teatati esimest korda avalikult anonüümsele allikale viidates Veerpalule tehtud dopingutes- 
ti positiivseks osutunud A-proovi olemasolust. 14. veebruaril 2011 tuvastas Maailma Antidopingu Agentuur (World Anti-Doping Agency WADA) Veerpalu organismist 29. jaanuaril 2011 tehtud testi põhjal lubatud normist kõrgema kasvuhormooni (HGH - Human Growth Hormone) taseme, mis sai B-proovi näol mitteametliku kinnituse sama aasta 5. ja 6. aprillil Saksamaal Kölni laboris. 7. aprillil lahvatas Eesti Suusaliidu pressikonverentsil dopinguskandaal, millega kaasnes kuni kaks aastat hiljem jõustunud õigeksmõistva kohtuotsuseni tugev meedia ja avalikkuse tähelepanu. Pressikonverentsil tunnistas olümpiavõitja, et sai 15 . veebruaril teada positiivse dopinguproovi andmisest, kuid kinnitas, et ei ole keelatud aineid tarvitanud ei võistlusväliselt ega võistlustel. 23. augustil 2011 määras Rahvusvahelise Suusaföderatsiooni (FIS) kolleegium sportlasele dopingu tarvitamise eest kolmeaastase võistluskeelu. Otsus kaevati advokaat Aivar Pilve abiga edasi spordiarbitraažikohtusse. ${ }^{2}$ Rahvusvaheline Spordiarbitraažikohus mõistis Veerpalu 2013. aasta 25. märtsil õigeks ja tühistas võistluskeelu, kuna WADA testis (WADA isoform HGH test) arvestati kasvuhormooni piirmäärasid valesti ja esines protseduurilisi vigu.

Eri huvirühmade koondumine sündmuse ümber ja vastastikune võimendumine ehk sotsiaalne resonants sai alguse kutselisest ajakirjandusest ja väljendus rohketes uudistes, igale uuele uudiskillule järgnenud aruteludes ja kommentaarides, mitmes aktsioonis, nt sportlasele poolehoidu väljendavates sotsiaalmeediarühmitustes ja eri linnades korraldatud inimkettides. Folkloristile pakub sellises resonantsis huvi eelkõige tekkinud folkloor, mis emotsionaalses kommunikatsioonis tekib ja võib väljenduda väga erinevais žanreis, nt sündmuse järel sündinud ja levinud kuulujutulistes vandenõulugudes, naljades-anekdootides, kogukondlikes stereotüüpides.

On huvipakkuv, et teema üheks retooriliseks alustalaks sai uskumine ja usaldus. Üliemotsionaalses õhkkonnas polariseerus avalikkus mustvalgelt kaheks: need, kes uskusid, et Veerpalu pole dopingut tarvitanud ja on süütu, ning need, kes teda ei uskunud. Loomulikult leidus ka neid, kellele teema korda ei läinud, kuid nende ükskõikne hääl kahe vastasleeri vahel meedias kuigi suurt kõlapinda ei leidnud. Artikli põhieesmärk on näidata, millised uskumise ja usaldusega seonduvad mõttemustrid ja stereotüübid olid erisugustes vormides avaldunud dopingufolklooris valdavad, ja analüüsida, kuidas need mustrid osalesid laiemas sotsiokultuurilises raamis (tõsimeelse ja iroonilise diskursuse skaalal) rahvusliku müüdiloome teenistuses.

Uurimuse põhilise allikmaterjali moodustavad kahe aasta vältel (aprillist 2011 märtsini 2013) kogutud tekstid, põhiosas Veerpalu juhtumiga seoses Delfi (http://www.delfi.ee) uudisteportaalis ilmunud artiklite kommentaarid ja Facebookis sündmuse ajel loodud kogukonnalehtede postitused. 


\section{Teoreetiline raamistik}

\section{Dopingujuhtumi folkloor kui uudispõhine spordifolkloor}

Ajakirjaniku taustaga USA teadlane Russell Frank (2011) on nimetanud folkloori, mis sõltub meedia loodud teadmisest aktuaalsete päevasündmuste kohta ja kommenteerib neid, uudis(folk)looriks (newslore). Uudispärimus võib leida väljenduse väga paljudes folkloorivormides, nagu nt naljad (sh katastroofihuumor), ütlused, kuulujutulised linnamuistendid, digitöödeldud fotod, pilavad uudislood, trükiste vahesedelid, mitteametlikud ringkirjad, laulu- ja luuleparoodiad, kommerts- ja poliitreklaamid, koomiksid, animatsioonid jne. Ka kõnealuse dopingujuhtumi avalikustamise järel sündinud lood ja levinud mõttesuunad/uskumused omandavad uudispärimuse väärtuse, kui ammutavad ainest päriselt aset leidnud päevasündmustest ning on reageering nii meedias kajastatud sündmusele kui ka meediakajastustele endile. Ühtlasi kuulub see pärimus kitsamas mõttes spordifolkloori valdkonda, mida seob ühise tunnusena sporditemaatika (vt ka Voolaid 2003: 197). Spordifolkloorse käsitluse epitsentris on sportlane kui spordiprotsessi peategelane. Välja joonistuvad järgmised folkloorikandjate alarühmad: 1) sportlased ja sporditegelased, sh sportlased, spordipedagoogid (treenerid, kehalise kasvatuse õpetajad), sporditegelased (spordiametnikud, -ajakirjanikud, -meedikud jne); 2) spordihuvilised, sh aktiivsed fännid, juhuharrastajad, võistluspublik, ka nn tugitoolisportlased; 3) spordikauged (sh sportlaste, treenerite ja nende igapäevase tööga vähe kursis olevad) inimesed. Mõistagi ei saa tõmmata teravaid piire, millal konkreetne inimene kuulub ühte, teise või kolmandasse spordifolkloori kandjate rühma. Ühe spordiala spetsiifilise folkloori kandja ei pruugi midagi teada teise ala sportlaste slängist ega tunda vastavat pärimust ja sellest aru saada. Mingit osa spordihuviliste ja spordivõhikute folkloorist tunneb aga igaüks. Peale otsesemate spordiringkondade (rühmad 1 ja 2) põhjustas Veerpalu dopingujuhtum resonantsi ka kõige spordikaugemas folkloorikandjate rühmas (3), kelle suhe spordiga seonduvasse kujuneb eelkõige meedia vahendusel või näiteks tuttava suust kuuldu järgi. Enamasti teevad võhikud oma järeldused sekundaarsete allikate põhjal, kuid väga laia kandepinnaga või huvisfääriga sporditemaatika (suurvõistlused) ei jäta neidki külmaks. Veerpalu dopingujuhtum jõudis kitsast sporditegelaste ja spordihuviliste ringist väljapoole. Välisring, tajudes ohtu oma rahva ja riigi mainele, reageerib sellele oma seisukohavõttude, eelarvamuste ja lugudega. Üldjuhul tekitavad laiemat vastukaja sporditipud ja/või (nii negatiivses kui ka positiivses mõttes) kära tekitanud atleedid. Just spordikauged inimesed väljendavad kõige laiemale üldsusele omaseid arusaamu, väärtushinnanguid ja mustvalget suhtumist sporti. Pärimusest võib kumada läbi emotsionaalne taust: 
igatsus olümpiavõitude, tiitlivõistluste medalite, aga ka kangelaste ja kuulsuste ümber ringlevate lugude, skandaalide ning intriigide järele. Käibelolev folkloor võimaldab summaarselt vaadelda, kuidas hinnanguid andes reageeritakse ja millised on üldisemad mõttesuunad: kui lootust äratanud olümpiasportlast tabab õnnestumise asemel ebaõnn (käesolevas uurimuses dopinguskandaali sattumine), tekivad sellest kohe vastava hinnanguga lood, stereotüüpsed seisukohad. Kuulujutuna levivaid keelatud ainete teemalisi spekulatsioone toetab üha tugevnev dopinguvastane võitlus ja tõsiasi, et dopingusüüdistustega tippsportlasi on viimastel aegadel väga palju esile kerkinud. Kõik skandaalsed juhtumid ja seigad pälvivad meedia ja avalikkuse teravdatud tähelepanu. Dopinguskandaalide kajastused peegeldavad tavaliselt pettumust sportlases, loobutakse olemast sportlasega ühes paadis ja käibele lähevad lood, mis sisaldavad negatiivset suhtumist ebaausasse käitumisse. Sellel taustal pakub huvi, millise suhtumise tõi endaga Veerpalu juhtum. ${ }^{3}$

\section{Olümpiavõitja kui rahvuskangelane - uskumine, usaldus ja vandenõulood}

Eestlaste rahvusliku eneseteostuse teel on muuhulgas olnud oluline ja emotsionaalne kogukondlik roll spordikangelastel, eriti olümpiavõitjatel (Peegel 1995; Kivine 1995: 18 jpt). Nimetamist väärivad nt 19. sajandi lõpul ja 20. sajandi algul eesti folklooris kajastunud raskejõustiklased - maadlejad ja tõstjad - ja nende kangelaslikkust esiletõstvad rahvajutud. Nende traditsiooniliste lugudega seostatakse oma järjepidevust ja identiteeti. Nii olid nt pikemaks ajaks traditsiooni kinnistunud pajatused esimese eestlasest maadlusvägilase Georg Lurichi kohta, ${ }^{4} \mathrm{nn}$ eeposlikud dimensioonid (vt Kivine 1995: 10) omandas eestlaste esimene olümpiakangelane Martin Klein hõbedase etteastega 1912. aasta Stockholmi olümpiamängudel peaaegu 12 tundi kestnud maadlusmatšil; rahva hulgas teatakse tänapäevani folkloorina levinud ergutusi 1936. aasta Berliini olümpiamängudelt kuldmedali toonud maadlussangar Kristjan Palusalule (Voolaid 2003: 213).

Kõnealuse dopinguloo üks tasandeid seostub samuti rahvusliku müüdiloomega. Murdmaasuusatamine, millega Veerpalu tegeleb, on nii kohalike kliimaolude kui ka harrastajate ja publiku rohkuse ning tipptulemuste tõttu lähiminevikus olnud Eesti olulisemaid rahvusspordialasid (ühemõtteliselt kajastub see 2007. aastal Eesti Suusaliidu 85. juubeliks ilmunud Tiit Lääne (2007) koostatud ajalooraamatu pealkirjas Suusatamine - Eesti rahvussport). Kahtlemata on pikaajaliste traditsioonidega ja avaliku huvi orbiidis olevate rahvusspordi staatuses alade esindajatel rahvuskangelase kuvandi loomisel 
tähtsam ja lihtsam roll kui nn vähemtuntud spordialade harrastajatel. Eesti murdmaasuusatajate (peale Veerpalu olümpiavõitja Kristina Šmiguni, aga ka Jaak Mae jt) edu tiitlivõistlustel on suusatamise olulist rolli etnilises enesemääratlemises põlistanud. Lisaks on Andrus Veerpalu oma isikuomaduste ja käitumisega rahvuskangelane kõige positiivsemas mõttes, selle staatuseni on sportlane jõudnud andekuse, aastatepikkuse tööga ja üliinimliku jõupingutusega, millele on aidanud kaasa ka eeskujulik isiklik elu ja viie lapsega pereisa seisus. Neile kangelase tingimuslikele omadustele osutasid ka mitmed dopinguskandaali puhkemise järel ilmunud eri valdkondade spetsialistide analüütilised tõlgendused. ${ }^{5}$ Folkloristlikus plaanis võib olümpiavõitja rolli seostada ka muinasjutukangelase rolliga, kes tegutseb rahvussangarina erilises, väga spetsiifilises tippspordimaailmas ja kelle eluteed võiks kirjeldada nt Vladimir Proppi klassikaks kujunenud, 1920. aastate lõpust pärineva universaalse imemuinasjutu struktuurimudeli kaudu (Propp 1969 [1928]). ${ }^{6}$ Mudeli kohaselt on kesksed kangelase teekond, katsumuste ületamine ja olümpiavõidu ning sellega kaasneva austusega päädiv õnnelik lõpp. ${ }^{7}$

Edukas tippsportlane on tänapäeval tuntud avaliku elu tegelane, kelle tulemused sõltuvad teda ümbritsevast suurest süsteemist, teda teenindavast üliprofessionaalsest personalist ja sponsoritest kuni kaasaelajate-fännideni välja. Tavaliselt ei esinda ta suurvõistlustel niivõrd ennast, kuivõrd just riiki ja rahvast. Nii on ka sportlase edu kogukonna edu, mille kaudu on võimalik mõjutada rahvuslikku eneseteadvust. Spordi ja rahvusluse seoses on Jyrki Pöysä rõhutanud, et globaliseeruvas ja meediapõhises hilismodernses maailmas võimaldab sport kogeda rahvustundeid mugavas ja (enamasti) turvalises ümbruses, kuigi mõnel juhul võib banaalne natsionalism muutuda kergesti avatud patriotismist agressiivseks huligaansuseks (Pöysä 2004: 56).

Positiivsuse säilitamiseks on inimestel motivatsioon hoida kõrget enesehinnangut. Seda saab teha, toetudes kahele mudelile - refleksioonile ja võrdlusele. Refleksioon esineb juhul, kui inimesed tunnevad ennast hästi teise inimese edu tõttu: nad muutuvad tähtsamaks teise inimese kuulsuse aupaistel (Habimana \& Massé 2000: 22). Refleksiooni ja võrdluse teooriast lähtuvalt võime eestlaste olümpiavõidu-igatsust ja sportlase kui kangelase ülistamist nimetada rahvuslikul tasemel refleksiooniks. (Meie) sportlase edu on ühtlasi terve (meie) kogukonna edu ja ka tasu (nt olümpiamedalid) peab rahvas piltlikult enda omaks. ${ }^{8}$ Niisugune kangelasega samastumine põhjustas ka dopingujuhtumis olukorra, mida nimetati meedias "kollektiivseks šokiks, rahvuslikuks traumaks, mis on võtnud religioosseid jooni" (Delfi juhtkiri 8. aprill 2011). ${ }^{9}$ Haavata ei saanud mitte üksnes dopingutarvitamisega vahele jäänud sportlane, vaid tema poolehoidjad ja kaasaelajad. Samal ajal erineb Veerpalu intsident, mis sai õigeksmõistva kohtulahendiga õnneliku lõpu, teistest sarnastest juhtumitest 
(vrd Kanada sprinter Ben Johnson, USA jalgrattur Lance Armstrong, Soome suusatajad Harri Kirvesniemi, Mika Myllylä jpt). Nõnda omandas negatiivne sündmus positiivse väljundi, mis turgutas rahvuslikke tundeid ja haaras inimesi.

Kõnealuse juhtumi näitel on olümpiasportlase kui rahvuskangelase ideega väga otseselt seotud ka usu ja uskumise teema. Omamoodi kvaasi- või parareligioonis pole küsimus enam ratsionaalsetes analüüsitulemustes ja mõõdetavates numbrites, vaid meedia mõjul tõuseb esile teema, kas kangelast uskuda/ usaldada või mitte. Inimeste suhtumine põhineb subjektiivsetel hinnangutel, seda nii kollektiivsel kui ka isiklikul tasandil. Käesolevas kirjutises saab usku käsitleda metafoorsena, pigem tähendab usk oma rahvuskangelase usaldamist. Olemuselt sarnaneb see kuulsuste jumaldamisega. István Povedák, kes on põhjalikumalt uurinud kuulsuste kultust Ungaris, on sedastanud, et "erinevate kuulsuste kultus sisaldab eri tasemel religioosseid komponente. [...] Sellist tüüpi kuulsuste kultus toimib religioosselt subkultuurilisel tasandil ja võib toimida fännide seas religioonina" (Povedák 2009: 9). Samas möönab ta, et seda ei defineerita tavamõistes religioonina, vaid kvaasi- ja pseudoreligioonina (quasi-, pseudo-religious belief).

Usu ja kangelase usaldamisega haakuvad dopinguskandaalidega seotud konspiratiivsed lood moodustavad uuema temaatilise spordijuttude ja -uskumuste rühma, millel on mõningaid ühistunnuseid tänapäeva linnamuistenditega. Tavaliselt levivad sellised lood kui kuulujutt. Enamasti iseloomustab neid anonüümsus, põhiloo rajanemine uskumusel või veendumusel, millele lisandub moraliseeriv osa (Kalmre 1996: 137-139). Ka internetikommentaarides levinud realistlikud dopingujutud räägivad tõestest või väidetavalt tõestest sündmustest ning võivad sisaldada irooniat ja üleloomulikkuse elemente, jättes samas suhteliselt usutava mulje.

Uurijad on osutanud, et nii nagu tänapäeva linnamuistendid, levivad ka vandenõuteooriad kriisisituatsioonides, millega kaasnevad hirmu ja kahtluse õhkkond ja ametlike (institutsionaliseeritud) infoallikate vaegus, ebamäärasus või koguni vastandlikkus (Kalmre 2000; Fine \& Ellis 2010; Madisson 2012: 39). Kuigi ametlikud meediaväljaanded esitasid pidevalt erisugust infot, kaasnes Veerpalu dopingujuhtumiga subjektiivsetel ja objektiivsetel põhjustel algusest peale teabevaegus, mis lõi umbusu ja usaldamatuse õhkkonna. Infoküllus ja infoallikate paljusus internetis võib viia peavoolu ja alternatiivsete infoallikate vastandumiseni. Uurijad on täheldanud, et välja pakutud vandenõuteooriates võib peavoolumeedias kajastatud ametlik tõde saada lausa vale sünonüümiks (Renard 2007: 225), usk konspiratiivsetesse lugudesse põhjustab avalike infoallikate suhtes radikaalselt skeptilise hoiaku (nt Keeley 1999: 121; Dentith 2012: 84). 
Vandenõuteooriate abil püüavad inimesed kuidagi otsida tõde ja leida vastust küsimusele, kas sportlast võib uskuda. Meedial on selles protsessis küll oluline roll, kuid inimese küsimusele ta tihtipeale lõplikult vastata ei suuda ning annab ise pidevalt signaale, mis ajendavad tavainimest saadud pooliku informatsiooni põhjal edasi mõtlema ja fantaseerima või varasemate kogemuste põhjal ise järeldusi tegema. Tihti üritavad vandenõuteooriad pakkuda oletatavaid alternatiivseid selgitusi, mis on ametlike allikatega vastuolus (Coady 2006: 119). Siinse uurimuse seisukohalt pakub huvi, millised vandenõulood konkreetse juhtumi järel esiplaanile kerkisid. Loomulikult ei saa lugude põhjal tõe jälile, kuid teema on inimeste silmis intrigeeriv, aktuaalne ja "rääkimist" väärt. ${ }^{10}$

\section{Mänguline huumor ja iroonia veebikommentaarides}

Juhtumi polariseerumist käsitlen kahe diskursuse abil. Tõsimeelne diskursus hõlmab olümpiavõitjat usaldavaid, kaitsvaid, toetavaid, heroiseerivaid kasutajakeskseid väljendusviise, aga ka vastaspoole tõsiseid väljaütlemisi. Irooniline diskursus katab sündmuse järel tekkinud igasuguse huumori (nt naljaparoodiad). Siia mahuvad ka ükskõikne üleolek teema suhtes ning sportlase ja tema toetajate suhtes negatiivse hinnanguga kommentaarid. Uurimuse allikaines pärineb internetist, kus huumor ja iroonia on sagedased ja täidavad mitmesuguseid eesmärke. Uurijad on väitnud, et liiga suur šokk, usaldusväärse info nappus ja kogu teema keerukus ei soodusta üldiselt naljategemist (vt Laineste 2009: 58). Ka Soome folklorist Ulla Lipponen on kinnitanud 2001. aasta murdmaasuusatamise MM-võistlustel Lahtis dopingukontrollis vahele jäänud kuue Soome suusatajaga seotud rahvusliku skandaali näitel, et irooniline toon ja nali olid vahetult pärast juhtumi ilmsikstulekut välistatud - rahvast tabanud šokk ei lubanud teemat naeruvääristada (vt SKS 2001: 13). Mõne aja pärast oli huumor aga valdav (ibid.).

Inimesi vapustanud sündmuste järel on folkloorile, sh narratiividele ja huumorile omistatud leevendavat teraapilist toimet (nt Kaivola-Bregenhøj 2005: 311; Kalmre 2009; Kuipers 2002: 453). Vestluste mängulised arendused võivad kohtuda, põimuda ja kumuleeruda väga erinevates kontekstides ja erinevatel tasanditel, sõltudes keskkonna olemusest ja funktsioonidest. Mänguline veebikommenteerimine pakub sotsiaalset rahuldust, sest see võimaldab väljendada tundeid ja hoiakuid (Virtanen 2013: 270). Olgu need tõsimeelsed või mitte, tõmbavad kommentaarid kohe sihtrühma kaasa. Rohket mängulisust, nalja ja vaimukust on peetud lausa arvutivahendatud suhtluse oluliseks omaduseks (vt nt Danet 1995; Danet et al. 1997). Ray Oldenburg (1999) on väitnud, et 
tõsidust veebikommuunides pigem välditakse ja taunitakse; samal ajal kui frivoolsus, verbaalne sõnamäng ja teravmeelsus on levinud. Hüpoteetiliselt on arvatud, et arusaamatuste suure tõenäosuse tõttu ollakse internetikeskkonnas naljategemise ja iroonia kasutamisega ettevaatlikud, kuid uuringud (nt Hancock 2004) näitavad vastupidist tendentsi. Nii on irooniline diskursus internetis iga avaliku arutelu loomulik osa, mille olemust tuleb uurida väga erinevatest perspektiividest. Niisiis on loomulik iroonilise diskursuse analüüs ka Veerpalu dopingujuhtumis, kus üldrahvalikud kogukondlikud hoiakud on tihtipeale esitatud mängulises ja iroonilises võtmes ning pakuvad võimsa alternatiivi tõsimeelsele siirale diskursusele.

Linda Hutcheon (1994) on väitnud, et marginaalsed rühmad kasutavad (põhiliselt postkoloniaalses ja feministlikus käsitluses) irooniat mängulise antidiskursusena, et öelda välja oma tõsine seisukoht valitseva idee suhtes. Iroonia on niisiis non bona fide mäng oluliste ideedega, sõnum on maskeeritud tõsidusega, jättes mulje tõsisest suhtlemisviisist. Jūratè Kavaliauskaitè (2009) on käsitlenud iroonia väljendusi meedias, pöörates tähelepanu intertekstuaalsusele, millel see põhineb. Mängimine žanrite ja ideedega on tema väitel iroonilise diskursuse põhialus. Jamie Warner (2008) on möönnud, et pingelised sündmused (nt 11. septembri terrorirünnak USAs) toovad esile iroonia, mis toitub valitsevast tõsisest diskursusest. Viimane aga sildistab kõik ametlikest interpretatsioonidest kõrvale kalduvad jäigalt "kahtlasteks, ebapatriootlikeks või isegi reetlikeks", vaieldes vastu neile, kes selliseid asju iroonia lõpuna käsitlevad (ibid.).

Veerpalu juhtumis sai mustvalge dualism avalikkusele võimsaks tõlgendusraamiks, mille alusel jagunes avalikkus uskujateks ja mitteuskujateks. Inimesed, kes sellesse raami ei mahtunud, esindasid pigem iroonilist diskursust, üritamatagi kuigi tõsiselt kaitsta seisukohta, kas sportlane rääkis õigust või mitte. Pigem kostus selle rühma iroonia kaudu kriitika mustvalge dualistliku arusaama ja selle meediavälja suhtes.

\section{Analüüs ja arutelu}

\section{Materjal ja meetod}

Uurimuse allikmaterjali moodustavad eelkõige kohtuskäigu (2011-2013) vältel Eesti suurimas uudisteportaalis Delfi dopingujuhtumi eri tahke kajastanud artiklite ja uudislugude (üldiselt anonüümsed) veebikommentaarid, mis on kogutud asünkroonse internetisuhtluse jälgimise teel, põhiline kogumismeetod 
on olnud avatud foorumi vaatlus. Kõik Delfi artiklid on lugejatele tasuta avatud ja eeldatavalt on kommentaarid suhteliselt vaba regulatsiooniga. Eri kaaluga uudis- ja arvamuslugusid ilmus Delfi portaalis vaatlusperioodi jooksul üle 300, paljud neist pärinesid päevalehtedest (Postimees, Päevaleht) ja olid Delfi kaudu ristviidatud. Valimis on 30 artiklit, mis kajastavad juhtumi olulisemaid etappe, enamik artikleid pärines juhtumi algusest, mil teema oli teravalt üleval ja ajendas ka enim arvamust avaldama. Kommentaaride arv on artikliti erinev, varieerudes 30 ja rohkem kui 1150 kommentaari vahel. Kokku on kommentaare peaaegu 4000. Juhtumi algusartikkel "Suusaliidu peasekretär Jüri Järv: meie poolt vaadatuna Veerpalu positiivset proovi ei ole" (Kukemelk 2011) pärineb 4. aprillist 2011 ja kogus 37 kommentaari, suurima arvu kommentaare ehk umbkaudu neljandiku üldarvust kogus 26. märtsil 2013. aastal ilmunud artikkel "Veerpalu sai spordikohtus võidu!" (Soonvald \& Rinaldo 2013), mis märkis ühtlasi ka pika saaga õnnelikku lõppu. Niisiis käsitlen kogu juhtumit ühe sündmusena ja oluline pole analüüsida mitte niivõrd pärimuse dünaamikat kronoloogilises mõttes, vaid teatud kategooriate avaldumist sündmuse kestel tekkinud folklooritekstides. Kirjutise eesmärk ei ole ka analüüsida professionaalset ajakirjandust, mis lõi sündmuse kommenteerimiseks ja uudisel põhineva folkloori tekkeks dünaamilise raamistiku. Meedias kajastus usu ja usalduse teema algusest peale, kuid see oli pigem reageering sotsiaalmeedia algatustele ja kirjeldas avalikkuse šokki (vt Delfi juhtkiri 8. aprillil 2011). Avalikkuse irooniline vastasus puhkes kõigepealt ajakirjanduse kui teema avalikustaja suhtes (Facebooki kogukond "Usume Andrus Veerpalu" kogus kiiresti Eesti esipäevalehe Postimehe jälgijatest suurema liikmeskonna, samal ajal kui Postimehe liikmeskond mõne päevaga kahanes) ja alles seejärel Veerpalu suhtes.

Delfi kommentaaride arvamusavaldused olid äärmiselt mitmekesised, ei puudunud neist ka ründavad nooled meedia kui sõnumitooja pihta. Vastavateemalise meediauuringu tulemused näitavad, et massimeedia kajastus Veerpalu dopingujuhtumi käsitlemisel oli kallutatud, pigem emotsionaalne ja provotseeriv kui ratsionaalne (Haavala et al. 2011: 15), mis omakorda mõjutas lugeja/rahva arvamusi ja reageeringut. Selline pinnas on ideaalne kasvulava kuulujuttude, vandenõulugude, stereotüüpsete klišeede tekkeks ja levikuks, ning välistab vähem atraktiivse ratsionaalse arutelu.

Võrdleva uurimisainese moodustavad nii solidaarsuse väljendusena loodud kui ka juhtumit naeruvääristavate Facebooki kogukondade postitused. Tuleb kindlasti arvestada, et võrreldes Delfi anonüümsete kommentaaridega esinevad Facebookis inimesed oma nime all ja see võib mõjutada mõnevõrra kommentaaride sisu (oma nime all on tugevam enesetsensuur). 
Suurim fännikogukond oli 7. aprillil 2011 loodud “Usume Andrus Veerpalu” (https:// www.facebook.com/pages/Usume-Andrus-Veerpalu/194487653920408?fref=ts, vt foto 1), mille liikmeskond edestas paari päevaga riigi suurima päevalehe Postimees Facebooki kogukonda. ${ }^{11}$ Kommuun kogus kiiresti üle 60000 liikme, mis näitas selgesti, kui olulist mõju avaldab rahva tunnetele sportlane, kes on oma tegude ja käitumisega rahva südames. Välisajakirjanduse hämmingut olukorra üle demonstreerib 9. aprillil 2011 ilmunud artikkel "Only a revolution has seen greater public feeling” (Ainult revolutsioon on näinud suuremaid avalikke tundeid). Artikkel kirjeldas eestlaste rajatud Facebooki kogukonda erakorralisena ja rõhutas võrdlevalt, et kui Suurbritannias ja USAs oleks dopingutarvitamisega vahele jäänud sportlane kohe põlu alla sattunud, siis Eestis on sotsiaalvõrgustikus loodud toetuskommuun kogunud 24 tunniga 50000 poolehoidjat, mis suhtarvuna eeldaks Suurbritannias 250000 inimese toetust (http://www.aninternationalobserver.co.uk/425 - ei ole enam kättesaadav).

Toetuskommuune lisandus veelgi, 7. aprillil 2011 loodi kogukonnad "Toetame Andrus Veerpalu"12, "Andrus Veerpalu is Clean"13, 8. aprillil 2011 loodi Facebookis kogukond "Tagasilöök Eesti meediale"14, mille idee on lühidalt sõnastatud postituses "Anname Eesti meediale Andruse materdamise eest raskel ajal tagasilöögi!!”

10. aprillil 2011. aastal toimusid toetuskogunemised Eesti linnade keskväljakutel, inimkette organiseeriti samuti eriotstarbeliste sotsiaalvõrgustike kaudu, nt "Andrus Veerpalu toetuseks inimkett/kogunemine"15.

Fännilehekülgedel postitajad on põhiosas Veerpalu poolehoidjad, kes juba leheküljega liitudes väljendasid tõsimeelset usaldust sportlasele. Retoorika viitab Veerpalu rahvuskangelase ainulaadsele oreoolile nii verbaalses kui visuaalses väljenduses. Kommuunide kirjeldused:

See mis hetkel Andruse ümber toimub on täiesti uskumatu ja mina arvan, et ta on suure toetuse oma pöidlahoidjate ja fännide poolt ära teeninud! Jõudu ja jaksu meie "Eesti Reliikviale”! (“Toetame Andrus Veerpalu”, https://www.facebook.com/pages/Toetame-Andrus-Veerpalu/158192334 241850?sk=info\&tab=page_info).

Toetavate kogukondade rahvuslik sümboolika (lipuvärvides avafotod) ja Veerpalust üles pandud fotod (nii Delfi artiklite juures kui ka sotsiaalmeedia toetuslehekülgedel sagedamini kas olümpiamängude võistlusfotod - rahvuskoondise vormis sportlane suusadistantsil tõsiselt pingutamas või autasuga fotod) näitavad selgesti, et aetakse Eesti asja ja kangelane on oma eriomases maailmas oma eriomases tegevuses ja hiilguses. 
Liialdatud toetuskampaaniatele tekkis ka vastasleere. 8. aprillil 2011 on Facebookis loodud kogukond "Usume Jõuluvana" (https://www.facebook.com/ pages/Usume-J\%C3\%B5uluvana/216788421669360?fref=ts), mida iseloomustab info:

Mitmekordne jõulupühade tooja, kauane talvetunde tarnija, mees meie kõigi südames on langenud usaldusauku! MEIE USUME JÕULUVANA!

Seotusele Veerpalu juhtumiga viitab peale kogukonna loomise aja ka jõuluvana profiilipildi all olev lisandus Sportlane (vt foto 2) ja postitused, nagu Jõuluvana on kasvuhormooni söönud päkapikk. Kogukonna liikmete hulk jääb siiski alla tuhande (5. veebruaril 2013 oli kogukonnal 881 toetajat). Toetusrühm tekkis kohe pärast dopinguskandaali puhkemist, ilmselt selgitab jõuluvana-kommuuni vähest poolehoidjate hulka tõsiasi, et rahvas oli teema üle naermiseks veel liiga suures šokis (vt eespool Lipponen 2001). ${ }^{16}$

Kahe mõnevõrra erineva andmekogu, artiklite kommentaaride ja Facebooki teemakohaste kodulehtede postituste esmane analüüs toimus kvalitatiivse andmetöötlusprogrammi Leximancer abil. Tekstianalüsaator võimaldas materjalimassiivis määrata levinumad põhimõisted (concept seeds). Andmetöötluse tulemusel sai kinnitust, et kommentaaride levinuim sõne on seotud uskumisega. Selgelt vähem relevantselt olid esindatud vastanduvad mõisted "meie" ja "nemad", "mina" ja "inimesed". Rohkelt esildusid skaalal ka juhtumiga seotud tehnilisse sõnavarasse kuuluvad "kasvuhormoon", "WADA", "Suusaliit" jt. Esmatasandi andmetöötluse toel sai kinnitust, et uskumise ja usalduse kategooriale keskendumine on käesolevas kirjutises õigustatud.

Teisene andmeanalüüs on temaatiline ja kesksed uurimisküsimused on järgmised. 1. Kuidas aruteludes väljendub uskumise ja usalduse kategooria, milliseid lugusid usutakse, millega usaldust põhjendatakse ja millistes (vandenõu) tõlgendusseostes uskumine kommentaarides ilmneb? Mida inimesed juhtumiga seoses usuvad/ei usu? Otseselt seondub uskumisega küsimus, kas uskuda Veerpalu, kes pressikonverentsil kinnitas, et pole keelatud aineid tarbinud ning lahkudes ka pisaraid näitas. 2. Milliseid folkloori-ja kultuurivorme (nt vandenõulugusid ja rahvusliku identiteedi väljendusi, huumorit) dopingujuhtum inspireeris? 3. Millised stereotüüpsed mõttemustrid ilmnevad? Kas uskuda, et ilma keelatud aineteta tippsport on tänapäeval üldse võimalik? Kas uskuda, et kogu juhtum on kellegi vandenõu ja sangar on süüdi lavastatud? 


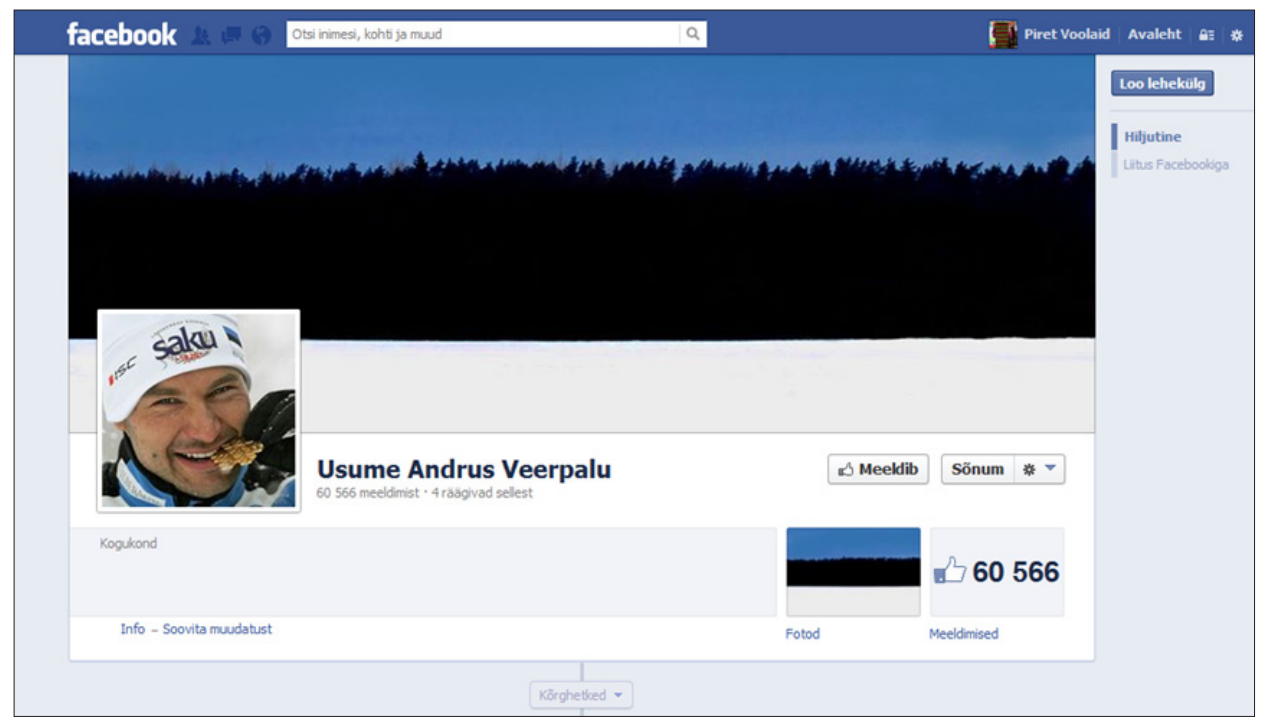

Foto 1. Toetust väljendav Facebooki kogukonna "Usume Andrus Veerpalu” avaleht (https: / / www.facebook.com / pages / Usume-Andrus-Veerpalu / 194487653920408?fref=ts).

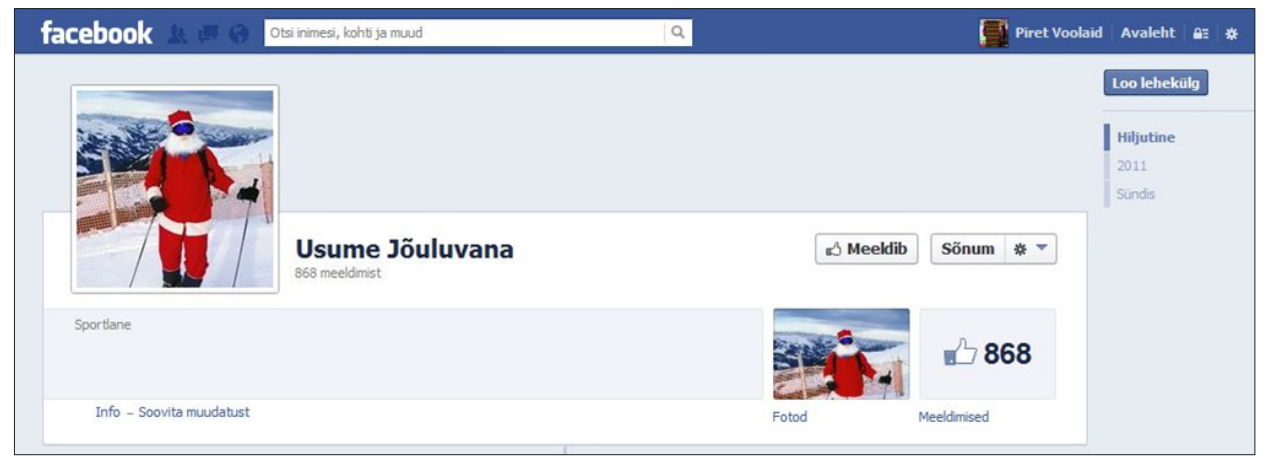

Foto 2. Facebooki kommuuni "Usume Jõuluvana" profiil (https: / /www.facebook.com / pages / Usume-Jõuluvana /216788421669360). 

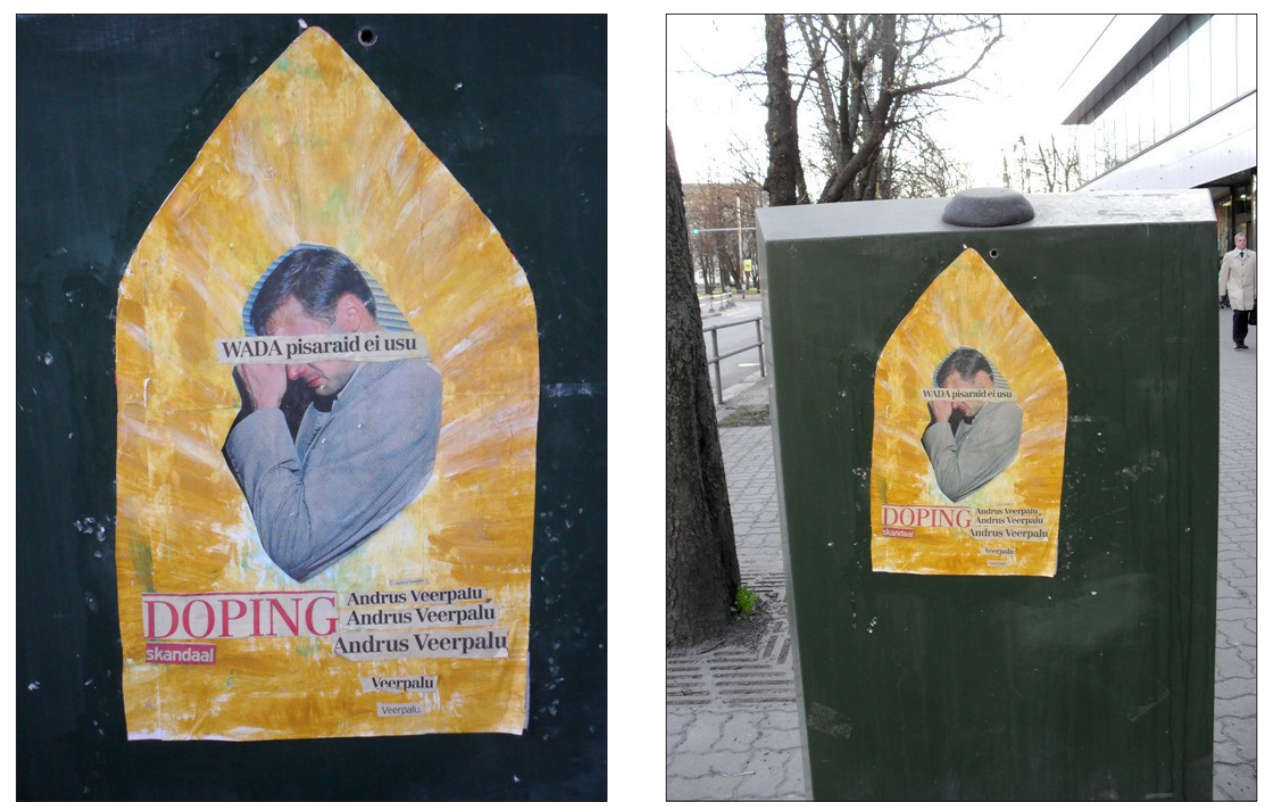

Foto 3. Üks väheseid sportlast pilavaid pilditöötlusi dopinguskandaali vältel. "WADA pisaraid ei usu" on ühtlasi viide omaaegse nõukogude menufilmi pealkirjale "Moskva pisaraid ei usu". Tallinna linnaruumis pildistatud poster levis hiljem internetis (http:/ / urbanepiphany.wordpress.com/page/5/).

\section{Usk, usaldus ja tõlgendusseosed}

"Rahvuslikku traumat, kollektiivset šokki" ja sellele järgnenud vastulööki kirjeldas Delfi 2011. aasta 8. aprilli juhtkiri "Usume Andrus Veerpalu” religioosse ilminguna: "On märter (Veerpalu), on usklikud ("kui oled ehtne eestlane, usud Veerpalu!") ja ketserid (ajakirjandus ning kainemalt mõtlejad). Valikuid on kaks - oled kas meiega või meie vastu." Kogu olukorda iseloomustas arvamuste väga tugev polariseerumine, üldjoontes olidki kommentaarid mustvalged ja kahesuunalised. Folkloorsest aspektist on Delfi kommentaarides ja Facebooki kogukondade postitustes kogu kaheaastase vaatlusperioodi vältel esiplaanil erinevad vandenõuversioonid.

Veerpalu usaldamist kinnitab nende protsentuaalne ülekaal, kes siiralt pidasid tõenäoliseks vigast testimismeetodit (ratsionaalseim põhjus) ja/või uskusid vandenõu. 
Alusena, millel usk põhines, rõhutati sportlase enda tunnistust:

Veerpalu sõnad "saan vanduda, et ma pole keelatud aineid tarvitanud" on nendele inimestele piisavalt veenev kinnitus. Nendest sõnadest aitab, et uskuda mehe sü̈̈tust (Delfi juhtkiri "Usume Andrus Veerpalu", http://sport.delfi.ee/news/suusatamine/eesti/anna-hinnang-veerpaludopingujuhtum-muutub-uha-mustilisemaks-mida-pikale-veninudsaagast-arvata. $d$ ? id=65749824).

Paljud toetajate kommentaarid olid kindlameelsed sisemised veendumused, mida ei peetud vajalikuks kommentaaris põhjendada:

Usun kindlalt Veerpalusse ja kogu tema meeskonda. Annaks jumal, et see jama ükskord lõppeks ja õiglus võidaks (virukas....... to Ruu, Delfi, 12. juuni 2012, http://sport.delfi.ee/news/suusatamine/murdmaasuusatamine/delfilausanneis-veerpalu-kohtusaagas-algas-teine-paev-jaak-mae-ilmubtunnistusi-andma.d?id=64528572\&com $=1 \& n o=20$ ).

Mõned toetajad kinnitasid, et isegi kui kangelane on keelatud ainetega patustanud, ei jäta nad teda raskel hetkel üksi:

Kõigele vaatamata on Veerpalu kõva mees ja Eestile küllaga kuulsust toonud. Suusaülekanded jäävad ära kindlasti. Kellele pakub huvi kui kordaminekuks loetakse 28. kohta (Ambur, Delfi, 6. aprill 2012, http:// sport.delfi.ee/news/suusatamine/eesti/allikas-andrus-veerpalu-a-proovoli-positiivne-sportlane-on-selle-vaidlustanud.d?id=43386223\&com=1\& no=140).

Suur osa Veerpalu uskujaid tõi esile testimismeetodi ebakindluse faktori. See põhjendus on ratsionaalselt ja tehniliselt objektiivseim, kuivõrd kasvuhormooni kõrgem tase organismis on bioloogiliselt võimalik ega tõesta veel keelatud aine tarvitamist. See oli nt ka kogukonna "Usume Andrus Veerpalu" argument, millele toetus üles ehitati:

Eesti Suusaliitu nõustava spetsialisti hinnangul võis 29. jaanuaril antud proovi tulemust mõjutada Veerpalu testieelselt toimunud tugev treening, mis kutsus esile kehaomase kasvuhormooni ülikõrge produktsiooni (https://www.facebook.com/pages/Usume-AndrusVeerpalu/194487653920408?sk=info).

Mäletatavasti tõigi testimismeetodi ebakindlus kogu saagale lõpuks õigeksmõistva kohtuotsuse. 
Paljudes kommentaarides nähti juhtumit rahvuslikult laetud probleemina, seejuures tajuti tugevat rahvusliku maine kahjustamist:

Kuigi vastaspoole eesmärk on tõestada igal juhul omapoolset õiget tegutsemist ja sportlase organismis dopingut - aga kui on või õhkõrn võimalus, et ta ei ole midagi tahtlikult valesti teinud ja tema süüdistus on ülekohtune, siis tuleb teha kõikvõimalik tema kaitseks. Terve sportlase enda ja tema perekonna elu on rikutud, rahvusriigi kogu sporditegemise maine on kahtlusega üle valatud (Ruu, Delfi, 12. juuni 2012, http:// sport.delfi.ee/news/suusatamine/murdmaasuusatamine/delfi-lausanneisveerpalu-kohtusaagas-algas-teine-paev-jaak-mae-ilmub-tunnistusi-and ma.d?id=64528572\&com $=1 \& n o=20)$.

Juhtumi rahvuslikus ühtsuses nähti lõhenemist, toodi ka sisse "meie" ja "nemad" vastandus, nimetati rahvusmeedia teemakäsitlust omade tümitamiseks: "Häbi on olla Eestlane: Miks te tümitate omasid, kui neid taga kiusatakse? Miks?" (tigekala, Delfi, 21. jaanuar 2013, http://sport.delfi.ee/news/suusatamine/eesti/ andreas-veerpalu-tahan-kaia-isa-jalgedes.d?id=65561856\&com=1\&no=20).

Rahvusfaktor ilmnes ka paljudes kommentaarides, milles usuti "norrakate vandenõu" (sünonüümsed väljendid "Norra karvane käsi sees" (Njaa, Delfi, 1. märts 2013, http://sport.delfi.ee/news/suusatamine/eesti/spordikohus-teataspohjuse-miks-veerpalu-otsuse-valjakuulutamine-edasi-lukati.d?id=65760846\&c $\mathrm{om}=1 \& \mathrm{no}=20)$ ). Selliste teooriate tausta moodustas mitu kokkusattumust, neist tähtsaim, et Veerpalu oli karjääri jooksul Norra suusatajate suurkonkurent. Oluliseks said kõik kaudsed asjaolud, nagu nt tõsiasi, et juhtumi esimesi kajastajaid ja sel teemal spekuleerijaid oli Postimees, mis kuulus Eesti Meediale, mille suuromanik oli juhtumi ilmsikstuleku ajal Norra kontsern Schibsted.

Eesti ja Norra konkurentsi väljatoomine on murdmaasuusatamise dopingukommentaarides universaalne, see motiiv esildus rahva reangeeringuna ka kohe pärast 2014. aasta veebruaris avalikustatud Kristina Šmigun-Vähi dopingukahtlust. Eredaimalt viitab sellele Eesti sotsiaalmeedias levinud fototöötlus (foto 4), millele on kõrvuti paigutatud Kristina Norra kuuekordse olümpiavõitja Marit Bjørgeniga. Mõlemad sportlased on pidulikus õhtukleidis, kontrasti moodustavad paljad käsivarred (Kristina Šmigun-Vähil peened ja naiselikud ja Marit Bjørgenil tugevad lihastes), mis annavad vaatajale tugeva visuaalse sõnumi selle kohta, kumb sportlane on dopingut tarvitanud. 

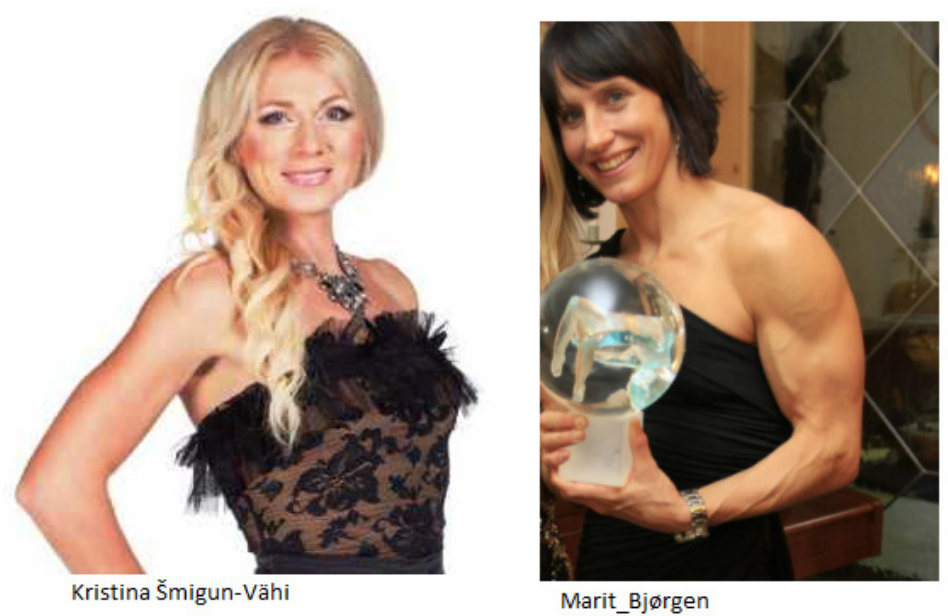

Marit_Bjørgen

Foto 4. Veebruaris 2014 internetis levinud meemiline fototöötlus "Kiku vs Marit Bjørgen" (http: / /itnurk.com/teema/300/157023/).

Toetajate sageda arusaama järgi on sportlane "ettur suures mängus", dopingujuhtumit seostati kättemaksuga treener Mati Alaverile:

Siin võivad olla ka põhjused Alaveri venitamisega seoses vene koondise treenerikohaga. Kui asi Andrusega nii on siis vaevalt ta sinna kohale saab ... (Spordisõber, Delfi, 6. juuni 2011, sport.delfi.ee/news/suusatamine/ eesti/allikas-andrus-veerpalu-a-proov-oli-positiivne-sportlane-on-selle-va idlustanud.d?id=43386223\&com=1\&no=20).

Sama idee, et tegemist on kellegi kättemaksuga just treenerile, teise kommentaatori sõnastuses:

Huvitav, miks Delfi nii verejanuliselt Veerpalu ründab - iga hinna eest on vaja mees madalaks vajutada. Kas kusagilt on kästud võimalikult mürgine olla?

Sellise hoiaku peale tekib küll küsimus, kas ei taheta siin ka ühtlasi Alaverile kätte maksta, et julges üldse Venemaaga arvestada oma edasistes plaanides (vandenõuteooria, Delfi, 8. aprill 2011, http://www.delfi.ee/ news/paevauudised/arvamus/juhtkiri-usume-andrus-veerpalu.d?id=43 $583009 \&$ com $=1 \&$ no $=40$ ).

Norrakate vandenõuversioonidele panustati kogu kaheaastase saaga vältel: 
No kuidas te lambad küll aru ei saa, et WADA test on pullikaka ja Norrakate poole kaldu FIS nägi head ettekäänet Andrusele "ära teha" (tigekala, Delfi, 21. jaanuar 2013, http://sport.delfi.ee/news/suusatamine/ eesti/andreas-veerpalu-tahan-kaia-isa-jalgedes.d?id=65561856\&com=1 $\&$ no=20).

Mõned kommentaatorid olid oma veendumuses väga resoluutsed, uskudes kindlameelselt kellegi pahatahtlikku vandenõu:

Olen aastaid jälgindsuurmeistri ilusad sõitu. 100 PROTSENDILISELT USUN VEERPALU AUSUST. USUN ET TEMAGIKAHLUSTAB KEDAGI (Idavirulane; Delfi, 12. juuni 2012, http://sport.delfi. ee/news/suusatamine/murdmaasuusatamine/delfi-lausanneisveerpalu-kohtusaagas-algas-teine-paev-jaak-mae-ilmub-tunnistusiandma.d?id=64528572\&com $=1 \&$ no $=0 \& s=1$ ).

Juhtum kanti üle muudesse valdkondadesse, seda seostati nt poliitikaga:

kahju jah kui veerpalu on sama mäda kui silmakirjalik eesti riik.. aga kala mädaneb peast !!!! (kahjuks jah, Delfi, 6. aprill, 2011, http://sport.delfi.ee/ news/suusatamine/eesti/allikas-andrus-veerpalu-a-proov-oli-positiivnesportlane-on-selle-vaidlustanud.d?id=43386223\&com=1\&no=60).

Skeptilist poolt esindavad kommentaatorid, kes seavad sportlase aususe kahtluse alla. Neis kommentaarides on esiplaanil teemast ükskõikne üleolek, mis väljendub negatiivse hinnanguga kommentaarides nii "naiivsete uskujate" kui ka patustanud tippsuusataja aadressil ning sündmuse järel tekkinud iroonias, naljaparoodiates.

Skeptikute hääles võib kõlada samuti mööndustega toetus, isegi kui usutakse, et sportlane on patustanud:

Kuulge naiivitarid, absoluutselt kõik tipud panevad midagi, olgu see siis täna keelatud või tundmatu... küsimus lihtsalt, kellel paremini arenenud spordimeditsiin on (vr, Delfi, 6. aprill 2011, http://sport.delfi.ee/ news/suusatamine/eesti/allikas-andrus-veerpalu-a-proov-oli-positiivnesportlane-on-selle-vaidlustanud.d?id=43386223\&com=1\&no=20).

Keelatud ainete kasutamine on nende väitel normaalne paratamatus, niisiis pole siin midagi erakordset ka käesoleva juhtumi korral:

Tahaks teada,kes ei kasuta vastavaid aineid.Kõik kasutavad.,mis siin arvatakse siis, et lihtsalt inimesed ongi kiiremaks muutunud lihtsalt niisama või? See on ebaloogiline. Sama ebaloogiline.kui et inimene on ahvist arenenud. Sel juhul oleks iga päev mõni uus ahv-inimene juures:))) 
(mök, Delfi, 12. juuni 2012, http://sport.delfi.ee/news/suusatamine/ murdmaasuusatamine/delfi-lausanneis-veerpalu-kohtusaagas-algasteine-paev-jaak-mae-ilmub-tunnistusi-andma.d?id=64528572\&com=1 $\&$ no $=20)$.

Kommentaare läbib väga tugevalt kinnistunud traditsiooniline arvamus stiilis:

No kes see tänapäeva spordis dopingut (või astmarohtu) ei kasuta? Kasutavad kõik, mõnel ei lähe see enne õiget aega välja jne (Kalle, Delfi, 6. aprill 2011, http://sport.delfi.ee/news/suusatamine/eesti/allikas-andrusveerpalu-a-proov-oli-positiivne-sportlane-on-selle-vaidlustanud.d?id=43 386223\&com $=1 \&$ no $=120$ ).

Kommenteerijad näisid väga hästi teadvat, kuidas tegelik spordielu käib:

Naiivsed on need, kes usuvad, et tippsporti pudru ja kartulitega tehakse, kahjuks on see meie päris elu ja teha suuri silmi ja kedagi sõimata on ülimalt silmakirjalik (Ibid, Delfi, 6. aprill 2011, http://sport.delfi.ee/ news/suusatamine/eesti/allikas-andrus-veerpalu-a-proov-oli-positiivnesportlane-on-selle-vaidlustanud.d?id=43386223\&com=1\&no=120).

Või isegi kui muudel spordialadel on võimalik ka ausa mängu reeglitega tipptulemusi saavutada, siis just Veerpalu alal mitte:

kui muul spordialal on võimalik ande ja töökuse pealt tippu jõuda ilma kanget kraami manustamata siis suusatamises mitte (Aabram, Delfi, 12. juuni 2012, http://sport.delfi.ee/news/suusatamine/ murdmaasuusatamine/delfi-lausanneis-veerpalu-kohtusaagas-algasteine-paev-jaak-mae-ilmub-tunnistusi-andma.d?id=64528572\&com=1 $\& r e g=0 \& n o=0 \& s=1)$.

Laialt esindatud uskumise diskursust täiendas (ja sellele vastandus) irooniline ja skeptiline diskursus, mida iseloomustas üleolev suhtumine eelkõige Veerpalusse ja osutused kangelase vääritule kukkumisele:

Ja mina ikkagi ei usu Veerpalut. Ja mind huvitab see, kes temaga koos selles jamas osalesid. Kes hankis, kes manustas ja kes olid teadlikud. Aga esmajoones lasub süü ikkagi sportlasel. Ja kangelane/suusasangar on inimene ja eksimine on inimlik. Ja ma ei viitsi seda vingumist enam lugeda ja kuulata. Kui sul on hunnik püksis, siis ainukene kes selle sinna lasta sai, oled sa ise. Kõik. Kangelast ei ole enam. Selleks oli vaja karjääri ôhtul ennast täis lasta ahnusest ja kuulssejanust (sic transit gloria mundi, Delfi, 8. aprill 2011, http://www.delfi.ee/news/paevauudised/arvamus/ juhtkiri-usume-andrus-veerpalu.d?id=43583009\&com=1\&no=0\&s=). 
Iroonilist diskursust iseloomustas kriitiline ja üleolev suhtumine kogu skandaali, meediasse, see andis hävitava verbaalse vastulöögi usaldavatele kirglikele pooldajatele ja väljendus radikaalselt vastanduvas hoiakus. See diskursus ilmnes eelkõige negatiivsete irooniliste kommentaaride arvus, aga ka juhtumit parodeerivates huumorivormides, mida võis vähesel määral täheldada vahetult pärast dopinguteema ilmsikstulekut, kuid üha enam kohtusaaga arenedes.

Väljendati pettumust, et ametnikud on rahvast teabeväljal petnud:

JÄRELIKULT KOGU SEE SELTSKOND, KES SUUSALIIDU JUHATUSSE KUULUB, MEILE VALETANUD!!!! jörelikult- EI SAA NEID TEGELINSKEID KA MUUDES ASJADES PÕRMUGI USALDADA!!! (nii on, Delfi, 6. aprill 2011, http://sport.delfi.ee/news/ suusatamine/eesti/allikas-andrus-veerpalu-a-proov-oli-positiivnesportlane-on-selle-vaidlustanud.d?id=43386223\&com=1\&no=140).

Kommentaatorid süüdistasid ajakirjanikke kuulujuttude levitamises ja väljamõtlemises ning kahtlesid uudise tõeväärtuses (vt eespool Renard 2007). Selline olukord saab tekkida, kui osa infot jäetakse lugejate eest varju. Järgnev kommentaator üritab ise meedia stiili järele teha ja loob ironiseerides hüperboolseid, võimendatud kuulujutte Eesti poliitikute kohta.

Teeme nüüd niimoodi, et ajakirjandus leiab ametliku allika ja toob konkreetsed faktid lagedale, enne me seda teemat edasi ei aruta. Mitte keegi ei pea hakkama kuulujutte ümber lükkama. Sama hästi võiks pasundada, et Ansip on tulnukas ja nii ongi, seni kui ta keeldub seda väidet kummutamst. Ja siis võtame järgmise prominendi käsile... Laaril on sohilaps. Langi sünnipäevapeol suitsetati kanepit. Keit Pentus on tegelikult mees, aga ta nõustus 10000 euro eest naiseks riietuma, et Eesti valitsuse vähemalt üks naine oleks... Tegelikult poleks mul midagi selle vastu, kui Pentus selle väite Playboy kaanel ümber lükkaks... Nii et "vaba ajakirjandus”, andke tuld! (qwe, Delfi, 6. aprill 2012, http://sport.delfi.ee/ news/suusatamine/eesti/allikas-andrus-veerpalu-a-proov-oli-positiivnesportlane-on-selle-vaidlustanud.d?id=43386223\&com=1).

Väga palju leidub toetajate kommentaarides kriitikanooli probleemi käsitlemisviisi pihta:

Dopinguskandaal pole täna leiutatud ja muidugi peab sellest ka rääkima. Tehakse igal pool. Kuid see kuidas Delfi, Postimees vöi Eskpress on lugu presenteerinud, on olnud labane nöiajaht, millel pole midagi pistmist ajakirjandusega. NN "uudisega” sooviti ainult tösta lugejate arvu ja teenida kollast raha (Rusikas, Delfi, 8. aprill 2011, http://www.delfi.ee/ 
news/paevauudised/arvamus/juhtkiri-usume-andrus-veerpalu.d?id=435 $83009 \&$ com $=1 \&$ no $=0 \& s=1$ ).

Kogu usu ja usaldamise emotsionaalse välja dokumenteerimisel väärib eraldi tähelepanu Delfi artikkel (Soonvald \& Rinaldo 2013), mis kajastas õigeksmõistvat kohtuotsust ja kogus 1150 kommentaari. Vandenõulugusid need enam ei sisaldanud, valdav osa kommentaare oli kantud rõõmust ja joovastusest, edastati õnnesoove nii sportlastele kui ka kogu rahvale (Õiglus pole veel maailmast kadunud! Palju õnne Andrusele ja meile kõigile! ${ }^{17}$ ), toetajad andsid oma usule tagantjärele hinnangu: Vahet poleks olnud, kumbapidi see uudis oleks tulnud. Andrus on pakkunud siiski uskumatuid elamusi paljudel aastatel ja neid mälestusi ei kustuta miski. : ${ }^{18}$. Samas kostus rohkete joovastuspostituste vahele ka vastaste rahulolematu hääl: Ütluse "Võitjate üle kohut ei mõisteta" asemel tuleb käibele ütlus "Kohtu üle võitu ei mõisteta"19. Skeptikud küsisid, kas see kohtuvõit tõestab sportlase süütust piisaval määral.

Iseenesest on huvitav, et kuu aega enne õigeksmõistvat kohtuotsust, 28. veebruaril 2013 korraldas Delfi gallupi "Mida arvata Andrus Veerpalu dopingujuhtumist?"20, et lugejate arvamus välja selgitada. Gallupile vastanuid oli 3212, valikuvõimalusi oli neli: (1) Veerpalule tehti ülekohut, tegemist oli vandenõuga $(26,4 \%, 848),(2)$ positiivne dopinguproov tulenes vigasest testimismeetodist (48,7\%, 1563), (3) Veerpaluga käituti õiglaselt, midagi kahtlast seal oli $(9,9 \%, 319),(4)$ positiivne dopinguproov pole juhus, alguses eitavad kõik $(15 \%, 482)$. Etteantud valikud on sellised, et inimesed saaksid tippsuusatajat näha kogu loos ohvrina, olgu siis tegemist vigase testimismeetodi, vandenõu või stereotüübiga, et puhast, keelatud aineteta sporti polegi tänapäeval olemas. Gallupi esimene valikuvõimalus osutab selgesti meedia eespool mainitud rollile konspiratiivteooriate levikus, vandenõu versioon ei tulenenud meedia võimetusest 'küsimustele vastata', vaid see oli meedia enda välja pakutud reageerimisvõimalus.

\section{Teemakohane huumor}

Dopinguskandaali puhkedes võis veebikogukondades ja kommentaariumides täheldada virtuaalseid vastasseise - niipea kui julgeti kangelasest "jumala" üle nalja visata, reageerisid kaaskommenteerijad sellele teravalt, tekkinud aruteludes aga kerkis taas esile pigem uskumise ja usalduse aspekt. Šokk ja usaldusväärse informatsiooni nappus lõid olukorra, kus rahvusliku tragöödia üle lubati endal nalja teha mõnevõrra hiljem. Siiski leidus Facebooki kogukonnas "Usume Andrus Veerpalu" värskete sündmusjärgsete kommentaaride hulgas 
anekdoote, mille positsioon oli sportlast toetav. Süžeedes osalesid sagedamini eesti suusatajate tugevad konkurendid, juhtivad Norra murdmaasuusatajad (nt Odd-Bjørn Hjelmeset), kelle puhtuses rahvasuus samuti kaheldakse.

nägin eila unes....

tulnud Hjelmeset (pärast viimaseid sündmusi) Otepääle käima... astunud kohalikku apteeki sisse, mananud näole megairwe, küsis apteekrilt: "Ega kasvuhormoone pole juhtumisi saada?"

"Einoh, ikka saab, aga vat astmarohud said otsa...meil siin suur mure, eesti suusakoondis jäi kõikseemees astmasse, ostsid kogu varu ära”... Hjelmel kukkus karp lahti, laup muutus higiseks, tormates uksest välja.. kaugenedes. kostis vaid tõlkimatu norrakeelne sõim

selline vat unenägu oli:) (Facebooki kommuun "Usume Andrus Veerpalu", 12. aprill 2011).

Spontaanselt loodud anekdootlikule unenäole on teine kommuuniliige lisanud omapoolse järje:

Seal samas Otepää kandis peale apteegist välja tulemist kurdab Hjelmeset: "Oeh, mulle taheti vastu tatti anda!” Juhuslik möödakäija: "Kuidas Sa seda tead?” Hjelmeset: "Muidu poleks ju antud!” (Facebooki kommuun "Usume Andrus Veerpalu", 12. aprill 2011).

Tekkis ka anekdoote otse Maailma Antidopinguagentuuri töökorralduse pihta, sest suur arvuline erinevus kahe dopinguproovi vahel tõusis meedias üles ja sellele sai apelleerida ka kohtus.

Rahvusvahelisel istungil vastab WADA pressiesindaja küsimustele, mis puudutavad Veerpalu dopinguproove.. Saalis tõuseb üks valges kitlis laborant ja küsib, kas panin paberile A-ja B-proovi vahe liiga suureks? Pressiesindaja: "Natuke jah, nü̈̈d oleme ka meie luubi all!” (Facebooki kommuun "Usume Andrus Veerpalu”, 12. aprill 2011).

Olukorda üritati naljaks pöörata ka põhjendusega, et Veerpalu tegelik üleolek on nii võimas, et ta lihtsalt selle pärast peabki tippspordist loobuma.

Või üli musta huumorit: Kuna Andrus valmistus astuma Eesti tavaellu, ei vastanud tema proovid enam võistlusnormidele ning otsustas tippspordist loobuda liigse üleoleku tõttu.

Väga vabandan: aga kes ei suuda nalja mõista- Tema ei vajaks lisa... abi võistlusteks:)Vaata veel (Facebooki kommuun "Usume Andrus Veerpalu", 12. aprill 2011). 
Veerpalu dopinguteema ja üldrahvalik sangari uskumine võidi siduda ka naljades muude eluvaldkondadega. 2013. aasta aprilli alguses levis Facebookis postitusnali, milles hiline kevad ja külm ilm on eestlastele karistuseks, et rahvas usub jumala asemel Andrus Veerpalusse.

“Oh Jumal, ole armuline, lase Andrus õigeks mõista!” anus rahvas pisarsilmi.

"Näidake, et usute!" kõmistas Jumal.

"Me usume! Me usume!" kisendas rahvas.

Ja saigi õiglus jalule seatud ja Andrus pattudest priiks.

"Kas teie usk on ikka veel sama kindel?" kahtles Jumal.

"Muidugi on!" koogutas rahvas. "Me oleme kogu aeg Andrusesse uskunud. Aegade algusest!"

"Ah et ebajumalat usute!" vihastas Jumal. "Virelege siis igavesti ebakevades ja olgu teil otsatu suusailm.” (Facebook, 2. aprill 2013).

See anekdoot käsitles juhtumit juba tagasivaatavalt, pärast kohtuotsust, mil igasugusel vabastaval naljal ja (enese)iroonial oli palju enam kohta.

Teema tähtsust avalikus arutelus kinnitavad kaks Postimehe päevakarikatuuri (fotod 5 ja 6), mis peegeldavad omal moel dopingujuhtumiga seotud arusaamu. Neist esimeses on keskmes Veerpalu kui rahvuskangelase puutumatuse oreool, mida on kaitsma asunud parajasti rahvusspordi suusatamisega tegelev eeposekangelane Kalevipoeg. Kalevipoeg rahvusliku tüvitekstina moodustab siin kogukondliku tekstiressursi (vt nt Kõresaar 2006: 105), mille kaudu on võimalik näha oma kollektiivset käitumist kõverpeeglis. ${ }^{21}$

On huvitav, et usu ja usaldamisega seotud iroonilist järelkaja on olnud mitmesugustes huumorivormides. Veerpalu juhtumit meenutas 2012. aasta 31. detsembril ETV eetris olnud Märt Avandi ja Ott Sepa aastavahetuse meelelahutussaate "Tujurikkuja 5" sketš pealkirjaga "Doping" (http://www. youtube.com/watch?v=g_lYsgcGeJQ), milles näitleja Ita Everit süüdistatakse etendusel keelatud ainete tarvitamises. Paroodia kutsus esile järellainetuse: Veerpalu skandaali eeskujul avati samal õhtul Facebookis fännileht "Usume Ita Everit!" (https://www.facebook.com/UsumeItaEverit?fref=ts), mis kogus kiiresti suure liikmeskonna ja ületas juba 1. jaanuari õhtuks 2000 toetaja piiri (nt 1. novembril 2013 oli lehel 3765 toetajat). Nüüdseks võib väita, et pärast Veerpalu dopingujuhtumit on "Me usume ..." kogukondade loomine klišeestunud, nt septembris 2013 said lauljatest kaksikõed Siiri ja Viivi Sõnajalg (pärast joobekahtlusega politseile vahelejäämist) Facebookis irooniast kantud toetuslehe "Usume Siirit ja Viivit" (Teeveer 2013), augustis 2014 sündis aga nn suudlusskandaali järel kogukond "Usume Evelin Ilvest" (https://www. facebook.com/usumeevelini?fref=ts). Folkloristlikust perspektiivist vaadatuna algatas Veerpalu juhtum niisiis uue kogukondade loomise traditsiooni. 


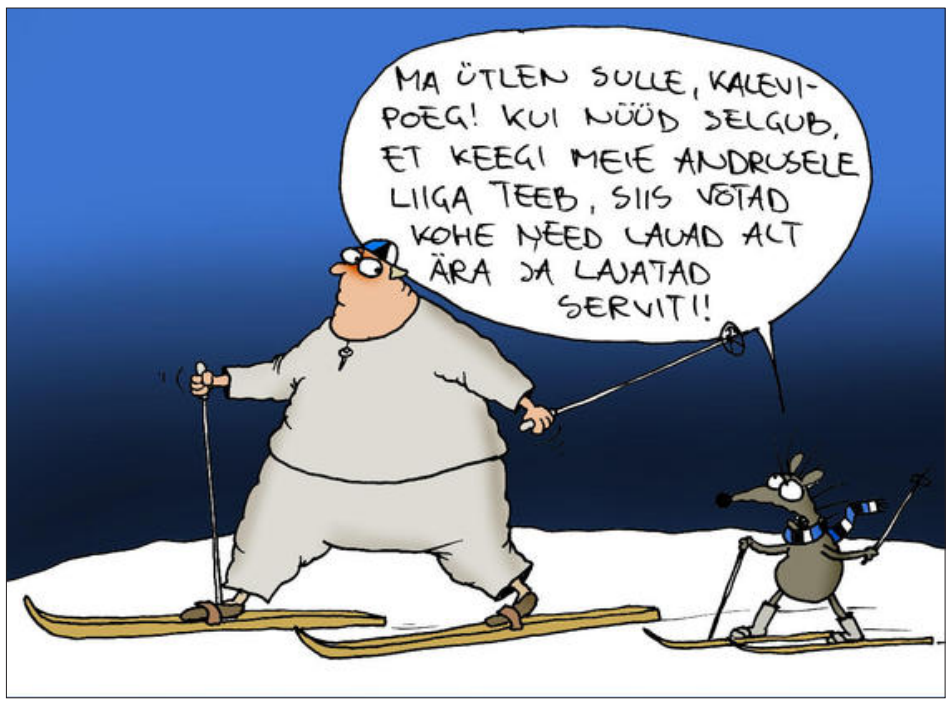

Foto 5. Urmas Nemvaltsi karikatuur ajalehe Postimees arvamusküljel (7. aprill 2011, http:/ /arvamus.postimees.ee/415846/paeva-karikatuurkaed-eemale-andrus-veerpalust).

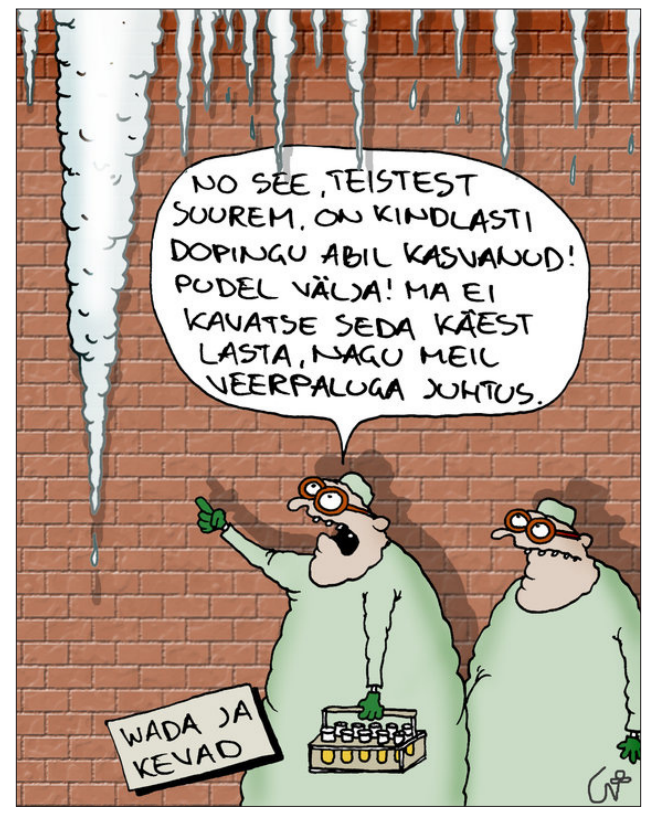

Foto 6. Urmas Nemvaltsi karikatuur Postimehes pärast õigeksmõistvat kohtuotsust (27. märts 2013, http: / / arvamus.postimees.ee / 1183244 / paevakarikatuur-wada-jatkab-voitlust). 


\section{Kokkuvõte}

Artikkel vaeb uskumise ja usaldusega seotud kollektiivseid hoiakuid, mis olid valdavad Andrus Veerpalu dopingujuhtumi vältel. Kogu teemakäsitluses on väga oluline osa professionaalsel meedial, kes kajastas algusest peale juhtumit ja suunas arutelu jõuliselt, kujundades usu ja usalduse metafoorilist ja retoorilist vaateviisi. Uudisteportaali Delfi korraldatud gallup kontrollis lugejate usu tugevust, paljud kujundid (nt Veerpalu nimetamine märtriks) lõid soodsa pinnase uskumise ja usaldusega seotud aruteludeks, mis raamistasid emotsionaalset juhtumit kaheaastase kohtusaaga vältel kuni teema vaibumiseni. Otsustamine, kas sportlast uskuda ja usaldada, põhines ennekõike irratsionaalsetel alustel, mitte aga tõenduspõhistel faktoritel.

Huviväärne oli, et dopingujuhtum käivitas omamoodi traditsioonilise usuliikumise - para-, kvaasi-, või pseudoreligiooni, mis põhines sõnumil, et Veerpalu kui rahva armastatud kangelane on oma tegude, elulaadi ja käitumisega pühak, mõneti võrreldav jumalaga, keda ei tohi mingilgi moel rünnata. Pisarates sangar mõjus 7. aprillil 2011 toimunud pressikonverentsil rahva tunnetele valusalt. Reaktsiooniks tekkisid vastavasisulised kommentaariumid ja sündisid sotsiaalmeediakanalites rahvaalgatuslikud rühmitused, millega väljendati sportlasele kõikvõimalikes vormides siirast toetust, aga toetajate vastukaaluks võidi kogu juhtumit pilgata ja selle üle ironiseerida. Üksteisele vastandusid inimesed, kes uskusid Veerpalu süütust, ning need, kes teda ei uskunud; kahe äärmusliku pooluse vahel olid olemas ka need, kes jäid pigem ükskõikseks kõrvaltvaatajaks ning suhtusid olukorda üleolevalt. Käsitlusalused kommentaarid, postitajate spontaansed väljaütlemised polariseerusid laias laastus kaheks vastanduvaks, kuid omavahel põimuvaks kategooriaks, mida on uurimuses vaadeldud tõsimeelse ja iroonilise diskursusena. Diskursuste vahekorrad olid kohtuprotsessi eri faasides dünaamilised. Vahetult pärast skandaali lahvatamist oli avalikkus šokis ja olümpiavõitja usaldajate seas valdav pigem siiras tõsimeelne toetus sportlasele, enda samastamine kangelasega ja esiplaanil küsimus, kas sportlase sõnu uskuda. Protsessi arenedes omandas üha suurema rolli huumor, sh iroonia. Usu ja usalduse kategooria arenes arutelude jooksul kuni õigeksmõistva kohtuotsuse kohta ilmunud artiklini, õnnelikust lõpust said toetajad jõudu, kuid ironiseerijate silmis ei tõestanud see Veerpalu süütust.

Meedia ja avalikkuse erakordne tähelepanu kanaliseerus mitmekesises päevakajalises uudisfolklooris, milles oli kesksel kohal kahtlusaluse uskumine/ mitteuskumine, usaldamine. Uudiste tõlgendamine ja mõtestamine sai sageli teoks narratiivide ja traditsiooniliste stereotüüpide, folklooritekstide kaudu, mis väljendasid erinevaid subjektiivseid tõdemusi ja olid kaugel erapooletust objektiivsest pildist. Nii tõsimeelne kui ka irooniline diskursus süüdistasid 
meediat ühekülgses teemapüstituses. Ametlikus meedias edastatud info oli sageli puudulik ja vastuoluline, dopingu testimine ise väga spetsiifiline ja tavainimesele hoomamatu valdkond, mis oli omakorda soodne vandenõulugude taimelava. Emotsionaalsetes lugudes said kangelaslikkuse väljenduseks rahvuslik uhkus (olümpiavõitja kui kangelase kuulumine rahvale, konkurentide soov Eesti sportlane hävitada (nt "Norra vandenõu"), Eesti mehe positiivse võrdkuju isikuomadused, murdmaasuusatamine kui rahvuslik spordiala jne), sportlase varasem positiivne kuvand. Uskumisest/mitteuskumisest olid kantud kuulujutuliste lugude mõttesuunad, mille kaudu üritati toimunut selgitada.

Veerpalu juhtumiga otseselt või kaudsemalt seotud verbaalseid ja visuaalseid kultuurivorme, mis käesoleva uurimuse tähelepanu alt välja jäid, tekkis ja levis kulutulena. Toetajate atribuutika hulka kuulusid ka T-särkidele trükitud loosungid ja plakatid inimketis. Ilmselgeid vihjeid Veerpalu juhtumile leidus 2012. aasta kevadel ETV-s linastunud põnevusseriaalis “Alpimaja” (stsenarist Indrek Hargla), mille tegevuse käivitab Eesti naisujujate olümpiavõidu tühistamine dopingutarvitamise tõttu.

Spordi funktsioonid on tänapäeval laienenud kehalise vormi ja vaimse heaolu väljendamiselt sotsiaalsete suhete edendamiseni, mis võimaldab pidada sporti ja spordiga seonduvat (iseäranis folkloorset) väljendust üheks kultuurivormiks. 2013. aasta detsembrikuus esitati Andrus Veerpalu õigeksmõistmine rahvusvahelises spordiarbitraažis Eesti aasta spordihetke konkursile. See põhjustas taas laialdase meediadiskussiooni ja rahva vastandumise kahte leeri, misjärel tegi kahekordne olümpiavõitja 10. detsembril 2013 avaliku pöördumise (Värv 2013) ja palus nominatsioon konkursilt eemaldada. ${ }^{22}$ Samas avaldati teade, et 10. detsembri hääletustulemuste põhjal juhtis Veerpalu õigeksmõistmine konkursil kindlalt.

Tänapäeva tippsportlane on avaliku elu tegelane, kes pakub kogukonnale emotsioone ning tema elu ja tegevus on pideva jälgimise all. Igaüks võib avaldada arvamust tema õnnestumiste ja ebaõnnestumiste, isikuomaduste ja isikliku elu kohta. Erakordsed olukorrad, ebainimlikud pingutused, nii vapustavad võidud kui ka skandaalsed kaotused põimivad tema avaliku kuvandi folklooritekstidesse. Meedia loob kangelasi, kuid võib meediaskandaali kiiluvees sangareid ka hävitada. Reaktsioonina võivad tekkida traditsioonilised müütilised lood, mis tõstavad kangelase rahvusliku sümboli ja ebajumala staatusesse. Eestlastel väikerahvana on vähe maailmatuntud suurnimesid ja kangelasi, aga rahvuse ülesehitamise müüdi juures tundub neid pidevalt vaja minevat. 


\section{Kommentaarid}

1 Artikkel on valminud ETA institutsionaalse uurimistoetuse IUT22-05 raames. Autori eriline tänu kuulub kolleeg Liisi Lainestele huumoriteoreetiliste nõuannete eest ja artikli anonüümsetele retsensentidele kõigi asjakohaste märkuste-soovituste eest.

2 11. juunil 2012 algas Rahvusvahelises Spordiarbitraaži Kohtus juhtumi käsitlemine kaebuse ärakuulamisega. Otsuse teatamist lükati korduvalt edasi. Kuni 29. jaanuarini 2011 oli Veerpalu andnud kogu sportlasekarjääri kestel üle saja dopinguproovi. Kõik need olid negatiivsed, nagu ka hilisem 2011. aasta veebruari alguses Davosi treeninglaagris antud proov. Kõigi olümpiavõitude ja muude tiitlivõistluste medalite eel ja järel on Veerpalu läbinud kohustusliku dopingukontrolli ning kõik need testid on olnud negatiivsed. Eesti Suusaliitu nõustava spetsialisti hinnangul võis 29. jaanuaril antud proovi tulemust mõjutada Veerpalu testi tegemisele eelnenud tugev treening, mis kutsus esile kehaomase kasvuhormooni ülikõrge produktsiooni. See oli objektiivseim argument, millel põhines avalikkuse usk Veerpalu puhtusse.

3 Viimasel ajal terves maailmas suurimat tähelepanu pälvinud juhtumina tasub meenutada USA jalgratturi Lance Armstrongi dopingutarvitamise epopöad, mille tagajärjel tühistas Rahvusvaheline Jalgratturite Liit (UCI) 2012. aasta oktoobris kõik Armstrongi seitse Tour de France’i võitu ja USA dopinguagentuur (USADA) määras talle eluaegse võistluskeelu.

${ }^{4}$ Georg Lurichi isikut, temast kõnelevaid jutte ning neis peegelduva väljamõeldise ja tegelikkuse vahekordi on oma uurimustes käsitlenud folkloristlikust aspektist Kalle Voolaid (2001: 186). Umbes saja Lurichist pajatava rahvajutu põhjal on ta jõudnud järeldusele, et enamik nendest ei põhine tegelikult aset leidnud sündmustel, Lurichi kujuga on seostatud ja mugandatud erinevaid vanemaid vägilasemotiive.

5 Tartu Ülikooli õppejõud ja maineuurija Aune Past näiteks andis ajakirjanikule intervjuu, kus nimetas Veerpalu erinevalt fantaasiakangelastest (Kalevipoeg) tegelikuks kangelaseks, kelleks ei saa hakata, vaid kelle seisus teenitakse välja raske tööga. Rahva poolehoidu ja erakordset toetust põhjendas ta sellega, et kangelasega tahetakse samastuda ja kangelasega tekib osalustunne, kuid dopingujuhtum tõstis õhku palju küsimusi: kas Veerpalu jutt on õige või vale, kas ta on kangelane või troonilt kukkunud kangelane ehk antikangelane, kas ta hakkab noori sportlasi treenima või hoopis jagama jahmatavaid intervjuusid teemal, kuidas ta dopingut kasutas (Šmutov 2011). Analoogselt räägiti rahvusliku "ausa soomlase müüdi" purunemisest Soomes pärast 2001. aastal Lahtis toimunud MMi, kui keelatud ainete tarvitamisega jäid vahele kuus Soome suusatajat - Janne Immonen, Jari Isometsä, Harri Kirvesniemi, Mika Myllylä, Milla Jauho ja Virpi Kuitunen (Lehtinen 2011: 12).

${ }^{6}$ Spordiajaloolane Kalle Voolaid on Proppi muinasjutufunktsioonidele allutades võrrelnud kahe omaaegse rahvussangari - Eesti maadleja Georg Lurichi (1876-1920) ja Soome pikamaajooksja Paavo Nurmi (1897-1973) elu ja sportlasekarjääri (vt Voolaid 1999: 55-64).

7 Folkloristlikult huvipakkuv oli ülejärgmisel päeval pärast teema üleskerkimist ilmunud psühholoog Voldemar Kolga (2011) artikkel, milles autor põhjendas Veerpalu suurt toetajaskonda müütilise kangelase teooria abil, viidates USA müüdiuurija Joseph Campbelli (2004: 28) 1940. aastail kasutusele võetud monomüüdi kontseptsioonile: “Tema kontseptsiooni järgi on kangelane inimene, kes lahkub igapäevasest elust, et võtta ette reis erilisse maailma, võtta vastu uusi väljakutseid, ületada enda hirmusid ja selle tulemusena saada mingeid autasusid, et neid hiljem jagada kangelase kogukonnaga, tema rahvaga" (Kolga 2011). 
8 Lähiminevikust (oktoobrist 2013) mäletame avalikkuse valulist reaktsiooni olümpiavõitja Erika Salumäe otsusele müüa võidetud medalid rahvusvahelisel oksjonil, mitte hoida neid rahva silme all muuseumivitriinis.

9 http://www.delfi.ee/news/paevauudised/arvamus/juhtkiri-usume-andrusveerpalu.d?id=43583009.

${ }^{10}$ Käesoleva juhtumi puhul tuleb arvestada, et dopingukahtlus on Eesti riiki esindavaid suusatajaid puudutanud ja eestlaste rahvuslikke tundeid haavanud varemgi. Meenutagem, et 23. jaanuaril 2002. aastal (Salt Lake City taliolümpiamängude eel) saabus Eesti Suusaliitu Rahvusvahelise Suusaliidu sõnum: Eesti kõigi aegade kuulsaima naismurdmaasuusataja Kristina Šmiguni dopinguproov on osutunud positiivseks. Nädal hiljem saadud B-proovi vastus oli siiski negatiivsne, kuid olümpiamängudel oli Šmiguni parim koht seitsmes ja rahvasuus levis vandenõule viitav arvamus, et dopingukahtlusega üritati sportlast sihilikult enne suurvõistlusi psüühiliselt kahjustada. 2002. aasta talvel tuli kasutusele etniline naljaküsimus: "Mis vahe on eestlasel ja soomlasel?" - "Eestlase B-proov on negatiivne." Selline rahvuslikku enesetunnet tõstev nali sobis hästi ajal, mil sarnaselt Kristina Šmiguniga olid dopinguproovid positiivsed ka Soome suusatajatel, kuid reeglitekohase järelproovi ehk B-proovi vastus oli Eesti suusatajal negatiivne, soomlastel aga tõesti positiivne. Niisiis leidis juhtum väga soodsa pinnase etnilise sisuga keerdküsimuseks, kuid on selge, et pärast Veerpalu dopinguskandaali see nali rahvasuus enam ei käibi.

2014. aasta veebruaris ilmus Vene spordiportaalis Ves sport uudis Kristina Šmigun-Vähiga seotud uuest dopingukahtlusest. 2006. aastal Torino olümpiamängude ajal võetud A-proov osutus positiivseks. Šmigun-Vähi valis teistsuguse lähenemise meediale kui seda tehti Andrus Veerpalu juhtumi puhul, ja tegi meedias avalduse, milles kinnitas kahtlustust, kuid eitas keelatud ainete kasutamist ja väitis, et on andnud vabatahtlikult valedetektori testi all tunnistuse, et pole elus kordagi teadlikult dopingut tarvitanud (Nilk 2014). Aprillis 2014 otsustas Šmigun-Vähi meeskond vaidlustada A-proovi avamise spordiarbitraaži kohtus.

11 10. aprillil 2011 tehtud postitusest pärineb statistika riikide osakaalu kohta kommuuni liikmeskonnas (55 753 Eesti, 2061 Soome, 848 Rootsi, 517 Ühendkuningriigid, 328 Ameerika Ühendriigid, 317 Norra, 146 Iirimaa, 140 Saksamaa, 134 Austraalia, 124 Hispaania, 113 Holland, 98 Taani, 80 Prantsusmaa, 76 Itaalia, 69 Läti, 66 Belgia, 64 Poola, 38 Luxembourg, 33 Venemaa). Võib oletada, et suuresti peegeldavad nimetatud arvud neis riikides resideeruvate eestlaste hulka Facebooki kommuunis. Viis kuud pärast positiivse dopinguproovi ilmsikstulekut, 19. septembril 2011 oli kogukonna "Usume Andrus Veerpalu" liikmete arv 66 795, täpselt kolm aastat hiljem, 19. septembril 2014 aga 58337.

${ }^{12}$ https://www.facebook.com/pages/Toetame-Andrus-Veerpalu/158192334241850?fref=ts, 15. novembril 2014 oli sellel 2721 liiget.

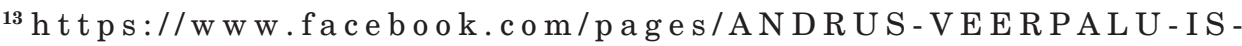
CLEAN/140506819353478?hc_location=timeline, 15. novembril 2014 oli sellel 478 liiget.

${ }^{14} \mathrm{https}: / /$ www.facebook.com/pages/Tagasil\%C3\%B6\%C3\%B6k-Eesti-meediale/1789120 58823734?ref=ts\&fref=ts, 5. veebruaril 2013 oli sellel 2396 poolehoidjat.

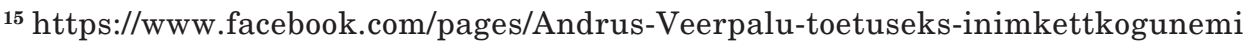
ne/216430721705353.

${ }^{16}$ Lehekülg pole esimene mõnd ühiskondlikku nähtust pilkav Facebooki paroodiakogukond. Eesti interneti-minevikus leidub küllalt analoogseid kogukondi, mille eesmärk 
on mõnda päevakajalist sündmust välja naerda, seda mõistu kritiseerida (nt 2010. aasta märtsis loodud lehekülg "Kas see kurk saab rohkem fänne kui Edgar Savisaar?", mille loojate eesmärk oli koguda rohkem liikmeid kui sai Savisaar valimistel hääli; seejärel omakorda huumori eesmärgil rajatud kogukond "Kas see redis saab rohkem fänne kui see kurk keda kõik fännavad?" jpt).

${ }^{17} \mathrm{http} / / /$ sport.delfi.ee/news/suusatamine/eesti/andrus-veerpalu-sai-spordikohtus-voidu $. \mathrm{d} ? \mathrm{id}=65878360 \& \mathrm{com}=1 \& \mathrm{reg}=0 \& \mathrm{~s}=1 \& \mathrm{no}=120$.

${ }^{18}$ Jaak, Delfi, 26. märts 2013 - http://sport.delfi.ee/news/suusatamine/eesti/andrusveerpalu-sai-spordikohtus-voidu.d?id=65878360\&com $=1 \& n o=60$.

${ }^{19} \mathrm{hmm}$, Delfi, 26. märts 2013 - http://sport.delfi.ee/news/suusatamine/eesti/andrusveerpalu-sai-spordikohtus-voidu.d?id=65878360\&com $=1 \&$ no $=60$.

${ }^{20} \mathrm{http} / / /$ sport.delfi.ee/news/suusatamine/eesti/anna-hinnang-veerpalu-dopingujuhtummuutub-uha-mustilisemaks-mida-pikale-veninud-saagast-arvata.d?id=65749824 .

${ }^{21}$ Olümpiavõitjaid ja rahvuseepose kangelast Kalevipoega on varem ühendatud mitmes kultuurivormis. Nt siirast austusavaldust olümpiasangaritele väljendab Põltsamaale rajatud Sõpruse park, mille tähtsaimad sümbolid on lähestikku asetsevad monumentaalskulptuur "Tee Olümposele" (Tauno Kangro, 2004; sammastele on kirjutatud kõigi Eesti olümpiamedalistide nimed) ning kündva Kalevipoja kuju (Tauno Kangro, 2006).

22 2013. aasta spordihetkena jäid konkureerima Eesti vehklejate Nikolai Novosjolovi ja Julia Beljajeva kuldne pooltund maailmameistrivõistlustel Budapestis (sai hiljem hääletamisvõidu), Eesti meeste korvpallikoondise jõudmine Euroopa meistrivõistluste finaalturniirile ja Eesti meeste jalgpallikoondise 2:2 viik Hollandiga.

\section{Kirjandus}

Campbell, Joseph 2004 [1949]. The Hero with a Thousand Faces. Bollingen Series XVII. Princeton \& Oxford: Princeton University Press.

Coady, David 2006. Conspiracy theories and official stories. Coady, David (toim). Conspiracy Theories: The Philosophical Debate. Hampshire \& Burlington: Ashgate Publishing, lk 115-128.

Danet, Brenda (toim) 1995. General Introdaction. Play and Performance in Computer-Mediated Communication. Journal of Computer-Mediated Communication, special issue 1 (2) (http://jcmc.indiana.edu/vol1/issue2/ - 15. september 2014).

Danet, Brenda \& Ruedenberg-Wright, Lucia \& Rosenbaum-Tamari, Yehudit 1997. "Hmmm... Where's That Smoke Coming From?" Writing, Play and Performance on Internet Relay Chat. Journal of Computer-Mediated Communication 2, issue 4 (doi: 10.1111/j.1083-6101.1997.tb00195.x).

Dentith, Matthew Richard 2012. In defence of conspiracy theories. Doctoral thesis. Auckland: The University of Auckland (https://researchspace.auckland.ac.nz/ handle/2292/17107 - 26. november 2014).

Fine, Gary Alan \& Ellis, Bill 2010. The Global Grapevine: Why Rumours of Terrorism, Immigration, and Trade Matter. New York: Oxford University Press (doi: 10.1093/acp rof:oso/9780199736317.001.0001). 
Frank, Russell 2011. Newslore: Contemporary Folklore on the Internet. Jackson: University Press of Mississippi.

Haavala, Kristina \& Koppel, Annika \& Loi, Karina \& Tuulik, Katrina \& Utkin, Mari 2011. Eesti meedia professionaalsus. Tallinna Ülikool, Kommunikatsiooni Instituut (http://uurimismeetodid.pbworks.com/w/file/fetch/46061836/Meedia_professionaalsus_ grupp_2.pdf - 26. november 2014).

Habimana, Emmanuel \& Massé, Line 2000. Envy Manifestations and Personality Disorders. European Psychiatry 15, nr 1, lk 1-7 (doi: 10.1016/S0924-9338(00)99501-4).

Hancock, Jeffrey T. 2004. Verbal Irony Use in Face-To-Face and Computer-Mediated Conversations. Journal of Language and Social Psychology 23 (4), lk 447-463 (doi: 10.1177/0261927X04269587).

Hutcheon, Linda 1994. Irony's Edge: The Theory and Politics of Irony. London ja New York: Routledge.

Kaivola-Bregenhøj, Annikki 2005. Uusiutuva arvoitusperinne. Saarikoski, Helena (toim). Leikkikentiltä. Lastenperinteen tutkimuksia 2000-luvulta. Tietolipas 208. Helsinki: Suomalaisen Kirjallisuuden Seura, lk 292-334.

Kalmre, Eda 1996. Vorstivabrikutest kassitoiduni ehk mõnda linnalugudest. Kõiva, Mare (toim). Mängult-päriselt. Tänapäeva folkloorist II. Tartu: Eesti Keele Instituut \& Eesti Rahvaluule Arhiiv, lk 136-155 (http://www.folklore.ee/rl/pubte/ee/cf/mjap/eda.html 26. november 2014).

Kalmre, Eda 2000. Katastroofifolkloorist: Estonia ja Titanic. Kõiva, Mare (toim). Meedia. Folkloor. Mütoloogia. Tänapäeva folkloorist III. Tartu: Eesti Kirjandusmuuseumi rahvausundi töörühm, lk 263-284 (http://www.folklore.ee/pubte/meedia/katastroofi. html - 26. oktoober 2014).

Kalmre, Eda 2009. Legends Connected with the Sinking of the Ferry Estonia on September 28, 1994. Kõiva, Mare (toim). Media \& Folklore: Contemporary Folklore IV, Tartu: Estonian Literary Museum Scholarly Press, lk 288-312 (http://www.folklore.ee/ rl/pubte/ee/cf/cf4/CF4_Kalmre.pdf - 26. november 2014).

Kavaliauskaitè, Jūratè 2009. Hybrid Entertainment Television: Viewership of the Lithuanian "Dviracio Sou". Krikmann, Arvo \& Laineste, Liisi (toim). Permitted Laughter: Socialist, Post-socialist and Never-socialist Humour. Tartu: ELM Scholarly Press, lk 99124.

Keeley, Brian L. 1999. Of Conspiracy Theories. The Journal of Philosophy 96 (3), lk 109 126 (doi: 10.2307/2564659).

Kivine, Paavo 1995. Te ei eksinud, härra parun! Slutsk, Aado (koost). Te ei eksinud, härra parun! Tallinn: Eesti Olümpiainfo, lk 3-10.

Koch, Tuuli \& Pahv, Peep 2011. Andrus Veerpalu ja doping: hästi hoitud saladus või laim? Postimees Online 2. aprill (http://sport.postimees.ee/412751/andrus-veerpalu-jadoping-hasti-hoitud-saladus-voi-laim - 26. november 2014).

Kolga, Voldemar 2011. Andrus Veerpalu kui (müütiline) kangelane. Delfi 9. aprill (http://www.delfi.ee/news/paevauudised/arvamus/voldemar-kolga-andrus-veerpalu-kuimuutiline-kangelane.d?id=43602631 - 26. november 2014). 
Kuipers, Giselinde 2002. Media Culture and Internet Disaster Jokes: Bin Laden and the Attack on the World Trade Center. European Journal of Cultural Studies 5 (4), lk 450-470 (doi: 10.1177/1364942002005004296).

Kukemelk, Epp-Mare 2011. Suusaliidu peasekretär Jüri Järv: meie poolt vaadatuna Veerpalu positiivset proovi ei ole. Delfi 4. aprill (http://www.delfi.ee/news/paevauudised/ eesti/suusaliidu-peasekretar-juri-jarv-meie-poolt-vaadatuna-veerpalu-positiivset-prooviei-ole?id=43249857 - 26. november 2014).

Kõresaar, Ene 2006. Kollektives Gedächtnis und nationale Textgemeinschaft im postsowjetischen Estland: Ein Beispiel über die intertextuelle Verwendung des Nationalepos "Kalevipoeg" in den estnischen Lebensgeschichten. Bartens, HansHermann \& Röhrborn, Klaus \& Sagaster, Klaus \& Winkler, Eberhard (toim). Ural-Altaische Jahrbücher. Internationale Zeitschrift für uralische und altaische Forschung. Neue Folge. Wiesbaden: Harrassowitz, lk 101-124 (http://www.academia. edu/1340193/Kollektives_Ged\%C3\%A4chtnis_und_nationale_Textgemeinschaft_im_ postsowjetischen_Estland_Ein_Beispiel_\%C3\%BCber_die_intertextuelle_Verwendung_ des_Nationalepos_Kalevipoeg_in_den_estnischen_Lebensgeschichten._H.-H._ Bartens_K._R\%C3\%B6hrborn_K._Sagaster_E._Winkler_Hrsg._._Ural-Altaische_ Jahrb\%C3\%BCcher._Internationale_Zeitschrift_f\%C3\%BCr_uralische_und_altaische_ Forschung._Neue_Folge_101_-_124_-_Wiesbaden_Harrassowitz_2006 - 26. november 2014).

Laineste, Liisi 2009. Political Jokes in Post-socialist Estonia (2000-2007). Krikmann, Arvo \& Laineste, Liisi (toim). Permitted Laughter: Socialist, Post-socialist and Neversocialist Humour. Tartu: ELM Scholarly Press, lk 41-72.

Lehtinen, Satu 2001. Go Finland Go! Universitas Helsingiensis 2, lk 11-12 (http://www. helsinki.fi/lehdet/uh/201b.htm - 26. november 2014).

Lääne, Tiit 2007. Suusatamine - Eesti rahvussport. Tallinn: Ajakirjade Kirjastus.

Madisson, Mari-Liis 2012. Vandenõuteooriate semiootiline tähistamisloogika.Akadeemia 6, lk 1024-1071 (http://www.academia.edu/2773751/Vanden\%C3\%B5uteooriate_semiooti line_t\%C3\%A4histamisloogika._Akadeemia_6_1024-1070_2012 - 26. november 2014).

Nilk, Andrus 2014. Kristina Šmigun-Vähile esitati dopingu-kahtlustus. Eesti Päevaleht 7. veebruar (http://epl.delfi.ee/news/eesti/kristina-smigun-vahile-esitati-dopingukahtlustus?id=67762685 -26 . november 2014).

Oldenburg, Ray 1999. The Great Good Place: Cafes, Coffee Shops, Bookstores, Bars, Hair Salons and Other Hhangouts at the Heart of a Community. Cambridge, Massachusetts: Da Capo Press.

Only a revolution has seen greater public feeling 2011. Views of an International Observer. http://www.aninternationalobserver.co.uk/425 - 20. aprill 2011 (pole enam kättesaadav).

Peegel, Juhan 1995. Vanu ajalehti sirvides. Slutsk, Aado (koost). Te ei eksinud, härra parun! Tallinn: Eesti Olümpiainfo, lk 11-18.

Povedák, István 2009. Heroes and Celebrities. PhD Dissertation Summary. Budapest \& Szeged (http://doktori.btk.elte.hu/folk/povedakistvan/thesis.pdf - 26. november 2014). 
Propp, Vladimir 1969 [1928]. Morfologiia skazki. Moskva: Nauka.

Pöysä, Jyrki 2004. "Finnishness" and "Russianness" in the Making: Sport, Gender and National Identity. Siikala, Anna-Leena \& Klein, Barbro Sklute \& Mathisen, Stein R. (toim). Creating Diversities. Folklore, Religion and the Politics of Heritage. Studia Fennica: Folkloristica 14. Helsinki: Finnish Literature Society, lk 54-68.

Renard, Jean-Bruno 2005. Negatory Rumors. From the Denial of Reality to Conspiracy Theory. Fine, Gary Alan \& Campion-Vincent, Véronique \& Heath, Chip (toim). Rumor Mills. The Social Impact of Rumor and Legend. New Brunswick, New Jersey: Transaction Publishers, lk 223-239.

Šmutov, Martin 2011. Maineuurija Veerpalu juhtumist: üliemotsionaalses olukorras on valikud must-valged. Postimees 8. aprill (http://sport.postimees.ee/416239/maineuurijaveerpalu-juhtumist-uliemotsionaalses-olukorras-on-valikud-must-valged - 26 . november 2014).

SKS 2001 = Folklore Archives of the Finnish Literature Society 2001. Flooded with doping humour. Universitas Helsingiensis 2, lk 13.

Soonvald, Urmo \& Rinaldo, Karl 2013. Andrus Veerpalu sai spordikohtus võidu! Otsus: on viiteid, et Veerpalu tarvitas dopingut, aga testi piirmäärad pole tõestatud. Delfi 26. märts (http://sport.delfi.ee/news/suusatamine/eesti/andrus-veerpalu-saispordikohtus-voidu.d?id=65878360 -26 . november 2014).

Teeveer, Ragnar 2013. Facebooki tehti Siiri ja Viivi Sõnajala toetusleht, uusi liikmeid lisandub iga minutiga. Delfi 27. september (http://rahvahaal.delfi.ee/news/ uudised/facebooki-tehti-siiri-ja-viivi-sonajala-toetusleht-uusi-liikmeid-lisandub-igaminutiga. $d$ ? id=66802793 -26 . november 2014 ).

Virtanen, Tuija 2013. Performativity in Computer-Mediated Communication. Herring, Susan C. \& Stein, Dieter \& Virtanen, Tuija (toim). Pragmatics of Computer-Mediated Communication. Volume 9 of Handbooks of Pragmatics. Berlin: Mouton de Gruyter, lk 269-290 (doi: 10.1515/9783110214468.269).

Voolaid, Kalle 1999. Lurich and Nurmi: Life as a Fairy-Tale? Acta Academiae Olympiquae Estoniae 7, lk 55-64.

Voolaid, Kalle 2001. Jõumehe fenomen: Georg Lurich ajaloolisest tegelasest rahvajutu kangelaseks. Jaago, Tiiu (koost). Pärimuslik ajalugu. Tartu: Tartu Ülikooli Kirjastus, lk 183-194.

Voolaid, Piret 2003. Jaanuar, veerpalu, märts, aprill, mae... Pilk spordimaailma läbi folklooriprisma. Mäetagused 21, lk 193-221 (doi: 10.7592/MT2002.21.spordifolkloor).

Värv, Maarja 2013. Veerpalu palus enda nominatsiooni spordihetke konkursilt eemaldada. ERR Sport 10. detsember (http://sport.err.ee/suusatamine/cf84e5f6-44a84a87-9340-1b41e7a0c6f1 - 26. november 2014).

Warner, Jamie 2008. Tyranny of the Dichotomy: Prophetic Dualism, Irony, and The Onion. The Electronic Journal of Communication 18: 2-4 (http://www.cios.org/www/ ejc/EJCPUBLIC/018/2/01841.html - 26. november 2014). 


\title{
Summary
}

\section{Olympic Champion as a National Hero: Folkloristic View to One Doping Case}

\author{
Piret Voolaid
}

Keywords: belief, conspiracy stories, fan culture, folklore about doping cases, national hero, national identity, sports folklore, stereotypes

The aim of the paper is to analyse the collective expression of attitudes elicited by the doping scandal that concerned the esteemed Estonian cross-country skier and Olympic gold medal winner, Andrus Veerpalu. The paper provides an insight into the evolution of an athlete into a national hero on the Internet.

The analysis is based on the material collected from Estonian online media during two years (from April 2011 to March 2013), when Andrus Veerpalu's court case was actively followed by the Estonian sports circles and laymen alike. The data corpus includes the most relevant news texts published in the online news portal Delfi (www.delfi.ee), comments from the same online environment, posts from the Facebook fan sites, e.g., "We believe in Andrus Veerpalu", etc.

The doping accusation called forth a quasi-religious movement, which was built around the belief that the athlete was sacred and it was not allowed to attack or accuse him in any way. The main threads in the comments analysed within this study could be divided into two opposing, although intertwining categories: the serious and the ironic. Both categories included people who believed in Veerpalu's innocence, and those who did not; in addition, there were those who displayed their superiority towards the entire discussion. The analysis addresses the transformation of an Olympic hero into a national hero, and points out narratives that treat the scandal within the present-day genres of urban legends, conspiracy theories, and Internet humour.

The more or less genuine belief of people was reflected in sought-out explanations for the doping test result and counter-arguments (above all, via conspiracy stories, but also through social mobilisation in support of Veerpalu). In the post factum comments, the majority expressed the feeling that their trust had been justified; they renewed their unremitting belief in the acquitted hero. But the rather complicated end to the long case was also a confusing one, and this allowed the ironic discourse to produce parodies, jokes and other critical comments.

The questions central to the analysis are the following: (1) How does the audience interpret information provided by the media and which topics do the interpretations initiate in turn? (2) How does the notion of belief emerge in the discussion, which narratives and stereotypes are believed in, and how is the belief rationalised? (3) Which folkloric and other cultural (transmedial) texts have taken inspiration from this doping scandal? 